\title{
Two new species of the genus Chamaesphecia Spuler, 1910 (Lepidoptera: Sesiidae), with remarks on the genus
}

\author{
Ава новых вида рода Chamaesphecia Spuler, 1910 \\ (Lepidoptera: Sesiidae) с замечаниями о роде
}

\author{
O.G. Gorbunov \\ О.Г. Горбунов
}

\begin{abstract}
A.N. Severtsov Institute of Ecology and Evolution, Russian Academy of Sciences, Leninsky prospekt 33, Moscow 119071, Russia. E-mail: gorbunov.oleg@mail.ru

Институт проблем экологии и эволюции им. А.Н. Северцова РАН, Ленинский проспект 33, Москва 119071, Россия.
\end{abstract}

KEY WORDS: Synanthedonini, Chamaesphecia efetovi, Chamaesphecia kalashiani, new species, neotype, systematics, Marrubium, Stachys, host plant, Palaearctic Region, Russia, Armenia, Azerbaijan

КЛЮЧЕВЫЕ СЛОВА: Synanthedonini, Chamaesphecia efetovi, Chamaesphecia kalashiani, новый вид, неотип, систематика, Marrubium, Stachys, кормовое растение, Палеарктический регион, Россия, Армения, Азербайджан

ABSTRACT. Two new species, Chamaesphecia efetovi sp.n. and Ch. kalashiani sp.n. from European part of Russia and from Armenia and Azerbaijan, respectively, are described and illustrated. Chamaesphecia oxybeliformis (Herrich-Schäffer, 1846), an insufficiently known species, is revised and a neotype is designated. The data on their biotopes and host-plants are presented as well.

РЕЗЮМЕ. Дано иллюстрированное описание двух новых видов бабочек-стеклянниц Chamaesphecia efetovi sp.n. из Европейской части России и Ch. kalashiani sp.n. из Армении и Азербайджана. Ревизован малоизвестный вид Chamaesphecia oxybeliformis (Herrich-Schäffer, 1846) с обозначением неотипа. Приведены данные о биотопах и кормовых растениях.

\section{Introduction}

The genus Chamaesphecia Spuler, 1910 (type species: Sphinx empiformis Esper, 1783) is one of the largest sesiid genera from the tribe Synanthedonini. Unfortunately, the exact number of species in the genus is currently difficult to name. The last checklist of the family contains 104 species of Chamaesphecia, but it includes some species from Neotropical, Afrotropical and Oriental Regions [Pühringer, Kallies, 2004]. It should be noted that the status of some taxa remains unclear and requires further investigation. In my opinion, the genus Chamaesphecia is restricted only to the
Palaearctic Region, and currently contains at least 99 species, including the two described below. As for the fauna of this genus in Russia, in the last list there were mentioned 16 of them [Gorbunov, 2008].

In 1990 this genus was divided into two subgenera [Laštůvka, 1990a]: Chamaesphecia s.str. and Scopulosphecia Laštůvka, 1990 [“1988"] (type species: Sesia alysoniformis Herrich-Schäffer, 1846). This nomenclatural act showed a clear paraphyly of the genus, in which subgenus Chamaesphecia and genus Weismanniola Naumann, 1971 (type species: Sesia agdistiformis Staudinger, 1866) are a monophyletic group [Laštůvka, 1992]. This problem can be solved in one way - to raise subgenus Scopulosphecia to a generic level. Perhaps this will be done in the near future.

In his remarkable work, Herrich-Schäffer [1846] described Sesia oxybeliformis Herrich-Schäffer, 1846 as a variation of Sesia masariformis Ochsenheimer, 1808 over a single male "aus Russland" [HerrichSchäffer, 1846: 70]. With a high degree of probability, this specimen was collected in the vicinity of Sarepta (Russia: Volgograd) by one of the German colonists or even Alexander K. Becker (1818-1901) himself. Subsequently, until the end of the twentieth century, this taxon was cited as an aberration [Staudinger, 1871, 1901; Spuler, 1910; Bartel, 1912; Dalla Torre, Strand, 1925] or a variety [Heppner, Duckworth, 1981] of Sesia annellata Zeller, 1847. However, back in 1967, Sterzl raised the rank of this nominal taxon to a full species level: "Chamaesphecia oxybeliformis H.S." [Sterzl, 1967: 191]. Unfortunately, the indication of this species for Austria turned out to be erroneous because the

How to cite this article: Gorbunov O.G. 2019. Two new species of the genus Chamaesphecia Spuler, 1910 (Lepidoptera: Sesiidae), with remarks on the genus // Russian Entomol. J. Vol.28. No.4. P.437-457. doi: 10.15298/ rusentj.28.4.13 
author pointed out Stachys recta (Lamiaceae) as a host plant for larvae of this species. Now we know that this woundwort is a host plant of Chamaesphecia dumonti Le Cerf, 1922. And thus, this indication for Austria should relate specifically to $C h$. dumonti. Somewhat later, Laštůvka [1983] noted Ch. oxybeliformis for Bulgaria on a female bred from the root of Marrubium peregrinum (Lamiaceae). From now on, Ch. oxybeliformis is always cited as a good species, although almost always with the remark that this is "an insufficiently known taxon" [Laštůvka, Laštůvka, 1995: 122, 2001: 89] or "the taxonomic status ... is unclear" [Špatenka et al., 1999: 363].

Since the nineties of the last century, I had the opportunity to breed clearwing moths from larvae in northwestern Kazakhstan, Armenia, Crimea and the Volgograd region of Russia. As a result of painstaking work, I managed to bring out a certain amount of imagines of Chamaesphecia (Scopulosphecia) spp. from various plants, including Marrubium peregrinum, Stachys spp., Phlomis herba-venti and Ballota nigra (Lamiaceae). So, all specimens bred from Ballota nigra, without any doubt, belong to Ch. annellata (Zeller, 1847). The specimens that were bred from the roots of Stachys recta and $S$. atherocalyx (Lamiaceae) from Crimea and the Volgograd region, I consider to be $C h$. dumonti, but those from S. iberica from Armenia - as a new species, which I describe below as Ch. (Scopulosphecia) kalashiani, sp.n.

A certain problem arose with the determination of specimens bred from Marrubium peregrinum and Phlomis herba-venti. Thus, specimens from $M$. peregrinum clearly belong to the $C h$. annellata species-group and are very similar to the specimen depicted in the work of Laštůvka [1983: 203, fig. 8]. After a thorough morphological analysis of the species of the Ch. annellata species-group, I clinched the conclusion that the specimens from Marrubium peregrinum belongs to an as yet undescribed species. Below I describe it as Ch. (Scopulosphecia) efetovi sp.n.

I bred three species of the genus from the roots of Phlomis herba-venti. All of them are different from the species on Marrubium peregrinum: Ch. ophimontana Gorbunov, 1991 in Armenia, Ch. djakonovi PopescuGorj et Căpuşe, 1966 from the Northwestern Caucasus and Crimean Mountains. Specimens that were bred from the Volgograd region and the lowland Crimea, I consider to belong to Ch. oxybeliformis. All these three species are very closely related and form a compact group, which is somewhat different from the Ch. annellata species-group, especially by the female genitalia (cp. Fig. 73 and Figs 74-76). Due to the fact that $C h$. oxybeliformis is "an insufficiently known taxon", and its type material has been lost [S patenka et al., 1999: 362], I revise it and, in accordance with the article 75.3 of the International Code of Zoological Nomenclature [ICZN, 1999], designate a neotype here.

All the images of moths were taken with a Sony $\alpha 450$ DSLR camera with a Minolta 50 Macro lens. The genitalia figures were obtained using a Keyence BZ-
9000 Biorevo Fluorescence Microscope. Final processing of all illustrations was performed with Adobe ${ }^{\circledR}$ Photoshop® CS5.

The material studied or mentioned below is kept in the following collections abbreviated in the text as follows: CKES - collection of K.A. Efetov, Crimean Federal University, Simferopol, Russia; COGM - collection of the A.N. Severtsov Institute of Ecology and Evolution, Russian Academy of Sciences, Moscow, Russia; ZISP - collection of the Zoological Institute, Russian Academy of Sciences, St. Petersburg, Russia.

All labels of the holotypes are cited verbatim. Each label is separated by semicolon marks, while lines on a label are shown separated by a slash ("/"). Pictures of the specimens are labeled with a number which consists of the name of the family, two consecutive digits and a year (e.g., SESIIDAE pictures №oo 0299-0300-2014). These numbers correspond to those of the illustrated specimens in the archives of the author. All dissected genitalia are placed in a microtube and pinned under the specimen. The genitalia number is also printed on a label (e.g., Preparation № OG-005-2018), pinned under the specimen and listed in the archives of the author. Specimens used for DNA analysis labeled with a red label with number (e.g. OGGS014).

\section{Descriptions}

\section{Chamaesphecia (Scopulosphecia) oxybeliformis (Herrich-Schäffer, 1846)}

Figs 1-16, 57-60, 73, 77, 78.

"[Sesia] Masariformis O. ... Oxybeliformis mas. ..." - Herrich-Schäffer, 1846: 69, pl. 7, fig. 36. Type locality: Russia, Volgograd Region, Ol'khovka District, Mikhailovka. Neotype ơ designated herein.

LITERATURE. Staudinger, 1871: 41 (Sesia annellata ab. ? oxybeliformis); Staudinger, 1901: 403 (Chamaesphecia annellata ab. oxybeliformis); Spuler, 1910: 311 (key), 314 (Chamaesphecia annellata ab. oxybeliformis); Bartel, 1912: 404 (Chamaesphecia annellata ab. oxybeliformis); Dalla Torre, Strand, 1925: 80 (Chamaesphecia annellata ab. oxybeliformis); Heppner, Duckworth, 1981: 34 (Chamaesphecia annellata var. oxybeliformis); Špatenka et al., 1993: 108 (Chamaesphecia oxybeliformis); Laštůvka, Laštůvka, 1995: 122, fig. 87, pl. 7, fig. 6 (Chamaesphecia oxybeliformis); de Freina, 1997: 227, text-figs 209, 213, pl. 17, figs 49-55, map 100 (Chamaesphecia oxybeliformis); Špatenka et al., 1999: 297 (key), 362, pl. 54, figs 453, 454 (Chamaesphecia oxybeliformis; part.); Laštůvka, Laštůvka, 2001: 20, 28, 42 (key), 88, fig. 89, pl. 7, fig. 6 (Chamaesphecia oxybeliformis); Pühringer, Kallies, 2004: 42 (Chamaesphecia oxybeliformis); Gorbunov, 2008: 112 (Chamaesphecia oxybeliformis); Anikin et al., 2017: 146 (Chamaesphecia oxybeliformis).

MATERIAL (31 $\sigma^{7} \bigcirc^{7}, 40$ 우). (Figs 1-16, 77, 78): $1 \bigcirc^{7}$, neotype (Figs 1-2), Russia, Volgograd Region, Ol'khovka District, Mikhailovka, $49^{\circ} 47^{\prime} \mathrm{N}, 44^{\circ} 24^{\prime} \mathrm{E}, 03-05$. VI.2002, ex larvae from a root of Phlomis herba-venti ssp. pungens (Lamiaceae), moth emerged 03.VII.2002, O. Gorbunov leg. (Sesiidae pictures №№ 0299-0300 2014) (COGM); 1 \%, "Beck.[er] Sarept.[a] [= Russia: Volgograd Region, vic. of Volgograd] (ZISP); $1 \mathrm{O}^{7}$, Ukraine, Crimea, Somferopol' District, Skvortsovo, 45 $5.452^{\prime} \mathrm{N}, 033^{\circ} 46.628^{\prime} \mathrm{E}, 39 \mathrm{~m}$, 03.VII.1988, K. Efetov leg. (COGM); 5 O $^{7} \sigma^{7}, 3$ 우, Kazakhstan, Atyrau Region, $60 \mathrm{~km} \mathrm{NE}$ of Kulsary, Imankara, $45^{\circ} 25^{\prime} \mathrm{N}, 054^{\circ} 30^{\prime}$ E, 08-10.V.1997, ex larvae from roots of Phlomis herba-venti ssp. pungens (Lamiaceae), moths emerged 24-25.VI.1997, O. Gorbunov 
leg. (COGM); 3 우 (Figs, 11-12), Kazakhstan, Aktyubinsk Region, $2 \mathrm{~km} \mathrm{~W}$ of Uil, $49^{\circ} 04^{\prime} \mathrm{N}, 054^{\circ} 37^{\prime} \mathrm{E}, 29 . \mathrm{V} .1998$, ex larvae from roots of Phlomis herba-venti ssp. pungens (Lamiaceae), moths emerged 29.VI-07.VII.1998, O. Gorbunov leg. (COGM); $1 \mathrm{O}^{7}, 7$ 우오, Russia, Volgograd Region, Kalach-na-Donu District, Evlampiyevskiy, $48^{\circ} 56^{\prime} \mathrm{N}, 043^{\circ} 34^{\prime} \mathrm{E}, 30 . \mathrm{V} .1999$, ex larvae from roots of Phlomis herba-venti ssp. pungens (Lamiaceae), moths emerged 26.VI-07.VII.1999, O. Gorbunov leg. (COGM); 5 O $^{7} \mathrm{O}^{7}$ (Figs 3-4), 4 우, Russia, Volgograd Region, Ol'khovka District, Mikhailovka, $49^{\circ} 47^{\prime} \mathrm{N}, 4^{\circ} 24^{\prime}$ E, 03-05.VI.2002, ex larvae from roots of Phlomis herba-venti ssp. pungens (Lamiaceae), moths emerged 03 11.VII.2002, O. Gorbunov leg. (Sesiidae pictures №№ 0291-0304 2014) (1 $\sigma^{2}$ with genitalia preparation № OG-044-2018) (COGM); $3 \sigma^{7} \sigma^{7}, 7$ 우, Ukraine, Crimea, Simferopol' District, Skvortsovo, $45^{\circ} 5.452^{\prime} \mathrm{N}, 033^{\circ} 46.628^{\prime} \mathrm{E}, 39 \mathrm{~m}, 24$.VI.2012, O. Gorbunov \& K. Efetov leg. (COGM); 4 O $^{7} 0^{7}, 7$ 우, same locality, 28.VI.2012, K. Efetov leg. (CKES); 4 o $^{7} \sigma^{7}, 1$ ㅇ, Ukraine, Crimea, Belogorsk District, $6.3 \mathrm{~km} \mathrm{NW}$ of Belogorsk, Sary-Kaya, $45^{\circ} 06.03^{\prime} \mathrm{N}$, 034 33.06' E, 230-245 m, 30.VI.2012, K. Efetov leg. (CKES); 4 o' same locality, 7.VII.2015, K. Efetov leg. (CKES); $3 \sigma^{7} \sigma^{7}$, Russia, Volgograd Region, Ol'khovka District, Mikhailovka, 49 $47^{\prime} \mathrm{N}$ $44^{\circ} 24^{\prime}$ E, 04.VI.2016, ex larvae from roots of Phlomis herba-venti ssp. pungens (Lamiaceae), moths emerged 28-29.VI.2016, O. Gorbunov leg. (Sesiidae pictures №№ 0405-0406-2016, 443-4442016, 0355-0356-2016) (COGM); 2 ○ $^{7} \sigma^{7}$ (Figs 5-6), 5 우 , Russia, Crimea, Simferopol' District, Skvortsovo, $45^{\circ} 05.483^{\prime}$ N, $033^{\circ} 46.673$ E, $41 \mathrm{~m}, 09$. VII.2017, O. Gorbunov \& K. Efetov leg. (Sesiidae pictures №№ 0103-0108-2018, 141-142-2018, 145-148-2018) (1 $\sigma^{7}$ with genitalia preparation № OG-023-2018; 1 q with genitalia preparation № OG-024-2018) (1 $\sigma^{7}$ and $1+$ with OGGS014 and OGGS015) (COGM); 3 O (Figs 13-14), Russia, Crimea, Razdol'noye District, $6.4 \mathrm{~km} \mathrm{~S}$ of Beryozovka, $45^{\circ} 03.95^{\prime} \mathrm{N}$, 034 $30.06^{\prime}$ E, 15 m, 22.VI.2018, O. Gorbunov \& K. Efetov leg. (Sesiidae pictures №№ 0459-0464-2018) (COGM); 4 O $^{7} \bigcirc^{7}, 2$ 우, Russia, Crimea, Tarkhankut, Olenevka, $45^{\circ} 25.16^{\prime} \mathrm{N}, 032^{\circ} 32.52^{\prime} \mathrm{E}$, $87 \mathrm{~m}, 13 . \mathrm{V} .2019$, ex larvae from roots of Phlomis herba-venti ssp. pungens (Lamiaceae), moths emerged 21-25.VI.2019, O. Gorbunov \& K. Efetov leg. (Sesiidae pictures №№ 0271-0282-2019) (COGM); $1 \sigma^{7}$ (Figs 7-8), 2 우 (Figs 15-16), Russia, Crimea, Dzhankoy District, Predmostnoye, $45^{\circ} 00.26^{\prime} \mathrm{N}, 035^{\circ} 15.58^{\prime} \mathrm{E}, 147 \mathrm{~m}$ 18.VI.2019, O. Gorbunov \& K. Efetov leg. (Sesiidae pictures №№ 0267-0270-2019) (COGM); 1 ఠ", 1 ㅇ, Russia, Crimea, Kerch peninsula, Kazantip, $45^{\circ} 28.089^{\prime} \mathrm{N}, 035^{\circ} 49.910^{\prime} \mathrm{E}, 13 \mathrm{~m}$. 21.VI.2019, O. Gorbunov \& K. Efetov leg. (Sesiidae pictures №№ 0263-0266-2019) (COGM); 1 +, Russia, Crimea, Belogorsk District, $5 \mathrm{~km} \mathrm{~W}$ of Belogorsk, $45^{\circ} 03.911^{\prime} \mathrm{N}, 034^{\circ} 30.148^{\prime} \mathrm{E}, 303 \mathrm{~m}$, 17.VII.2019, O. Gorbunov \& K. Efetov leg. (COGM).

DESCRIPTION. Male (neotype) (Figs 1-2). Alar expanse $20.5 \mathrm{~mm}$, body length $12.0 \mathrm{~mm}$, forewing $9.1 \mathrm{~mm}$, antenna $5.8 \mathrm{~mm}$

Head with antenna dark brown to black with dark greenish-violet sheen dorsally and yellow with golden hue ventrally, scapus black dorsally and yellow ventrally; frons graybrown with greenish-bronze sheen and a broad white stripe laterally; basal joint of labial palpus white with a few yellowish scales exterior-ventrally, mid joint white with a narrow black stripe exterior-ventrally and pale yellow scales exterior-dorsally in apical half, apical joint yellow with a few black scales distally; vertex orange with an admixture of black scales with greenish sheen medially; pericephalic hairs orange dorsally and white to pale yellow laterally.

Thorax with patagia dark brown to black with greenishviolet sheen and a few dark yellow or orange-yellow scales laterally; tegula dark brown to black with greenish-violet sheen, with broad orange inner margin and a small white to pale yellowish spot at base of forewing anteriorly; mesothorax dark brown to black with greenish-bronze sheen, with a narrow orange stripe anterior-medially and sparse, thin, orange, hair-like scales; metathorax orange with a tuft of orange hair-like scales laterally; thorax laterally dark-gray brown with blue-violet sheen and a large dark yellow to orange spot; posteriorly both metepimeron and metameron dark graybrown with a few white scales ventrally and white to yellowish hair-like scales. Legs with neck plate white with golden hue; fore coxa white with golden hue, an admixture of dark gray scales medially and yellow scales with golden hue externally at base; fore femur internally yellow with golden sheen, externally orange to yellow-orange with golden hue and dark gray-brown scales with blue-violet sheen in basal half; fore tibia ventrally yellow with golden hue, dorsally orange to yellow-orange with golden hue and an admixture of dark gray- brown scales with blue-violet sheen basally; fore tarsus orange to yellow-orange with golden hue and dark gray-brown scales with blue-violet sheen dorsally; mid coxa black with dark greenish-blue sheen; mid femur internally pale yellow with golden hue, externally black with dark blueviolet sheen and with yellow with golden hue anterior margin; mid tibia internally pale yellow with golden hue, externally orange to yellow-orange with golden hue and black scales with blue-violet sheen both basally and distally; spurs pale yellow to yellow with golden hue; mid tarsus orange to yellow-orange with golden hue and brown scales with bronze sheen externally on three apical tarsomeres; hind coxa black with dark greenish-blue sheen; hind femur internally pale yellow with golden hue, externally black with dark blueviolet sheen and with yellow with golden hue anterior margin and apically; hind tibia internally pale yellow with golden hue, externally orange to yellow-orange with golden hue and with a black stripe with blue-violet sheen ventrally from base to base of mid spurs and black scales with blue-violet sheen at base of apical spurs; spurs pale yellow to yellow with golden hue; hind tarsus entirely orange to yellow-orange with golden hue. Forewing dorsally black with greenish-blue sheen at base; costal and anal margins, $\mathrm{CuA}$-stem and apical area dark brown with bronze-violet sheen, but densely covered with orange to yellow-orange scales masking background colouration; veins within external transparent area orange to yellow-orange with golden hue; discal spot dark brown with bronze-violet sheen; transparent area well-developed, but densely covered with semitransparent scales with golden hue; posterior transparent area exceeding level of cross-vein of hindwing; external transparent area rather large with rounded distal margin, divided into five cells between veins $R_{3}$ and $\mathrm{CuA}_{1}$, level to vein $\mathrm{M}_{2}$ about 2.2 times as broad as discal spot and ca. 1.8 broader than apical area; ventrally costal and anal margins and basal half of $\mathrm{CuA}$-stem pale yellow with golden hue, veins within external transparent area and apical area yellow with golden hue; discal spot dark brown with dark blue-violet sheen and with an admixture of yellow-orange scales distally; cilia dark brown with bronze sheen basally and yellow-orange with golden hue distally. Hindwing transparent; dorsally veins yellow-orange with golden hue and a dense admixture of brown scales with bronze sheen on veins $\mathrm{M}_{3}-\mathrm{CuA}_{2}$, discal spot dark brown with bronze sheen, relatively broad with parallel margins, reaching base of veins $\mathrm{M}_{3}-\mathrm{CuA}_{1}$; outer margin brown with bronze sheen, narrow about 0.3 as broad as cilia; ventrally veins pale yellow to yellow; discal spot and outer margin dark brown with bronze sheen and with an admixture of a few yellow scales; cilia dark brown basally and yellow-orange with golden hue distally.

Abdomen dorsally black with dark blue-violet sheen; tergite 1 with a few yellow to pale yellow scales distally; tergites 2 and 4 each with a narrow pale yellow with golden hue stripe distally; tergites 6 and 7 each with more broad pale yellow with golden hue stripe distally; tergites 2, 4 and 5 each with a broad orange stripe subdistally; tergites 6 and 7 each with a narrow orange stripe subdistally; tergite 3 with a 

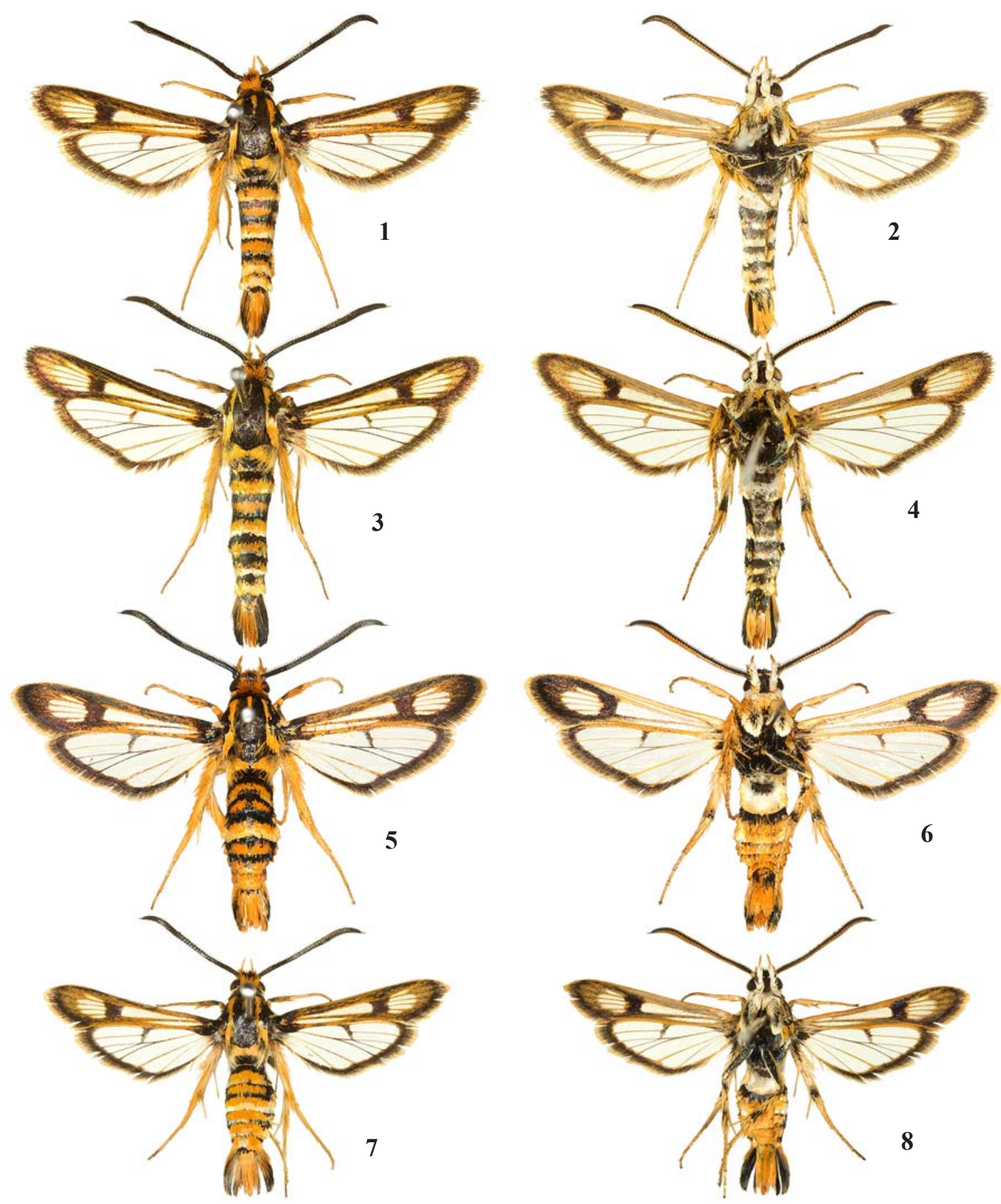

Figs 1-8. Variability of males of Chamaesphecia oxybeliformis (Herrich-Schäffer, 1846): 1-2 - neotype, Russia, Volgograd Region, Ol'khovka District, $2 \mathrm{~km} \mathrm{NW}$ of Mikhailovka, $49^{\circ} 47^{\prime} \mathrm{N}, 44^{\circ} 23^{\prime} \mathrm{E}, 03-05 . \mathrm{VI} .2002$, ex l., O. Gorbunov leg. (COGM). Alar expanse $20.5 \mathrm{~mm}$.

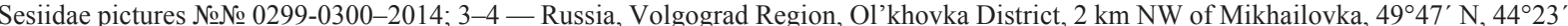
E, 03-05.VI.2002, ex l., O. Gorbunov leg. (COGM). Alar expanse $21.0 \mathrm{~mm}$. Sesiidae pictures №№ 0303-0304-2014; 5-6 - Russia, Crimea,

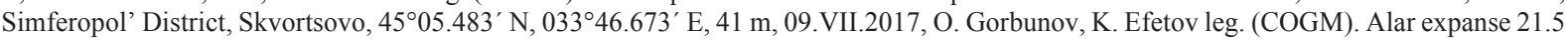
mm. Sesiidae pictures №№ 0145-0146-2018; 7-8 - Russia, Crimea, Dzhankoy District, Predmostnoye, $45^{\circ} 00.26^{\prime}$ N, $035^{\circ} 15.58^{\prime}$ E, 147 m, 18.VI.2019, O. Gorbunov, K. Efetov leg. (COGM). Alar expanse 19.0 mm. Sesiidae pictures №№ 0267-0268-2019.

Рис. 1-8. Изменчивость самцов Chamaesphecia oxybeliformis (Herrich-Schäffer, 1846): 1-2 — неотип, Россия, Волгоградская

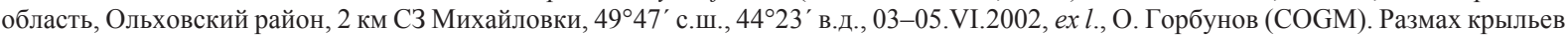
20,5 мм. Sesiidae снимки №№ 0299-0300-2014; 3-4 - Россия, Волгоградская область, Ольховский район, 2 км С3 Михайловки,

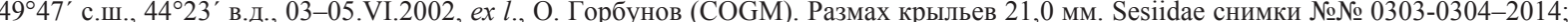

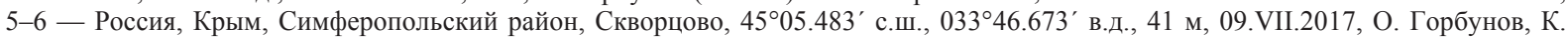
Ефетов (COGM). Размах крыльев 21,5 мм. Sesiidae снимки №№ 0145-0146-2018; 7-8 - Россия, Крым, Джанкойский район, Предмостное, $45^{\circ} 00.26^{\prime}$ с.ш., $035^{\circ} 15.58^{\prime}$ в.д., 147 м, 18.VI.2019, О. Горбунов, К. Ефетов (COGM). Размах крыльев 19,0 мм. Sesiidae снимки №№ 0267-0268-2019. 

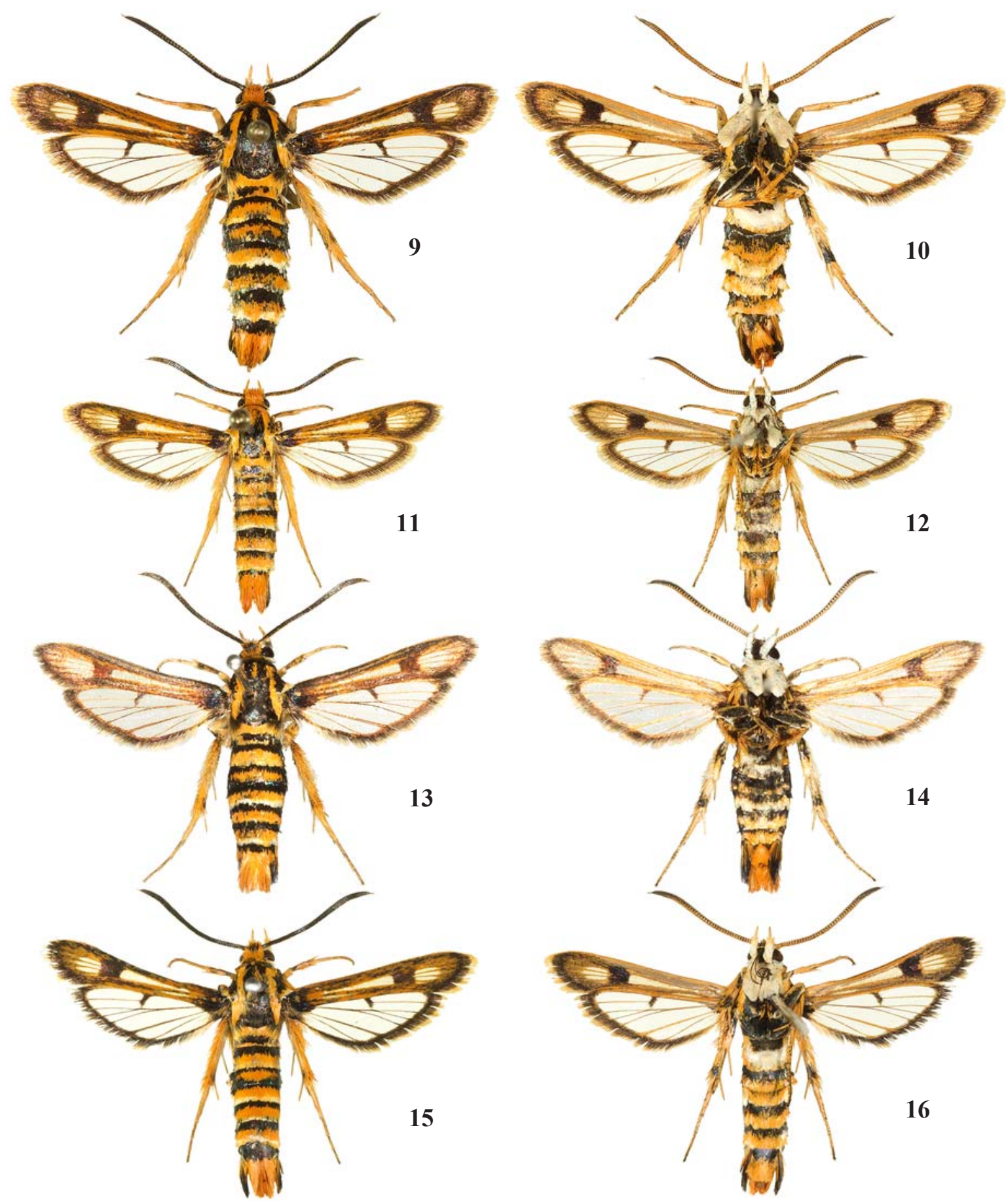

Figs 9-16. Variability of females of Chamaesphecia oxybeliformis (Herrich-Schäffer, 1846): 9-10 - Russia, Volgograd Region, Kalach-na-Donu District, Evlampiyevskiy, 4856’ N, 043³4' E, 30.V.1999, ex l., O. Gorbunov leg. (COGM). Alar expanse $22.0 \mathrm{~mm}$.

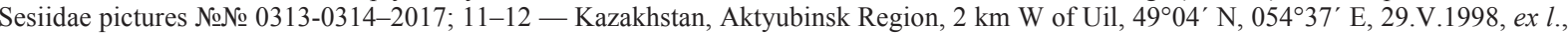
O. Gorbunov leg. (COGM). Alar expanse 17.1 mm. Sesiidae pictures №№ 0315-0316-2017; 13-14 - Russia, Crimea, Razdol'noye District,

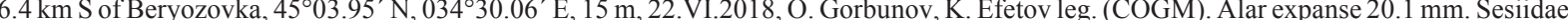

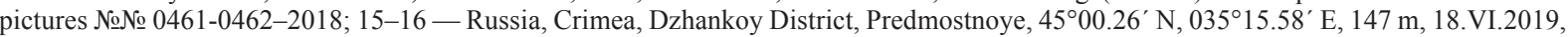
O. Gorbunov, K. Efetov leg. (COGM). Alar expanse $20.0 \mathrm{~mm}$. Sesiidae pictures №№ 0269-0270-2019.

Рис. 9-16. Изменчивость самок Chamaesphecia oxybeliformis (Herrich-Schäffer, 1846): 9-10 - Россия, Волгоградская область,

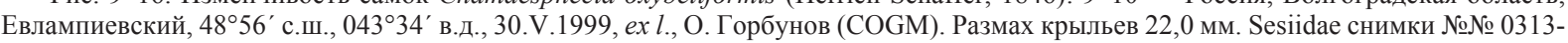
0314-2017; 11-12 - Казахстан, Актюбинская область, 2 км 3 Уила, 4904' с.ш., 054³7' в.д., 29.V.1998, ex l., О. Горбунов (COGM). Размах крыльев 17,1 мм. Sesiidae снимки №№ 0315-0316-2017; 13-14 - Россия, Крым, Раздольненский район, 6.4 км Ю Берёзовки,

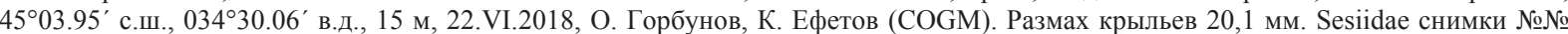
0461-0462-2018; 15-16 - Россия, Крым, Джанкойский район, Предмостное, 4500.26’ с.ш., $035^{\circ} 15.58^{\prime}$ в.Д., 147 м, 18.VI.2019, O. Горбунов, К. Ефетов (COGM). Размах крыльев 20,0 мм. Sesiidae снимки №№ 0269-0270-2019. 

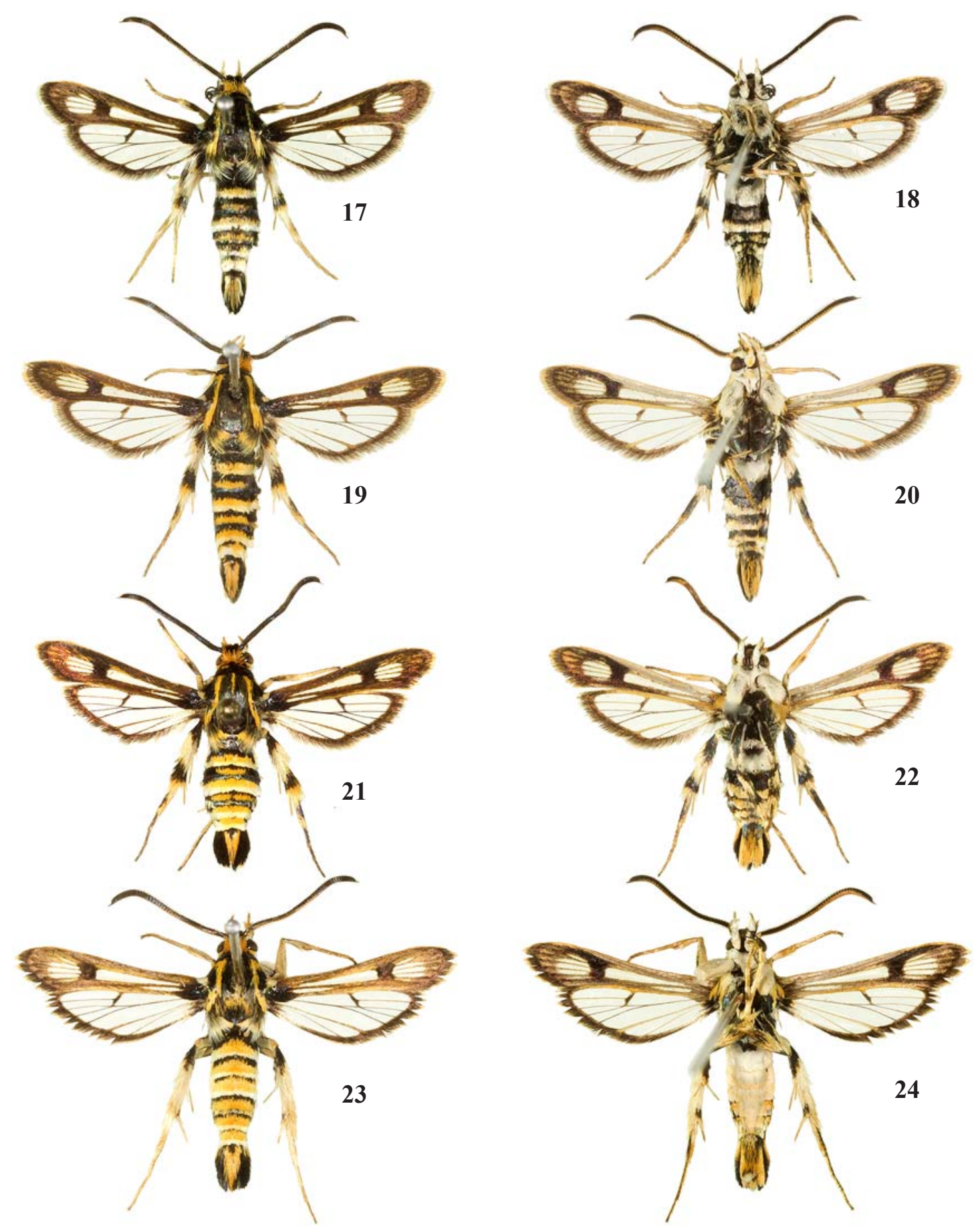

Figs 17-24. Variability of males of Chamaesphecia efetovi sp.n.: 17-18 - holotype. Russia, Crimea, 2.8 km NW of Kurskoye, Bor-

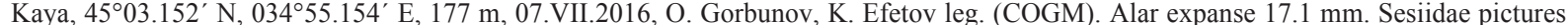
№№ 0303-0304-2016; 19-20 - paratype. Russia, Volgograd Region, Ol'khovka District, 2 km NW of Mikhailovka, 49 $47^{\prime} \mathrm{N}, 4^{\circ} 23^{\prime} \mathrm{E}$, 03-05.VI.2002, ex l., O. Gorbunov leg. (COGM). Alar expanse $18.5 \mathrm{~mm}$. Sesiidae pictures №№ 0331-0332-2017; 21-22 - paratype. Russia,

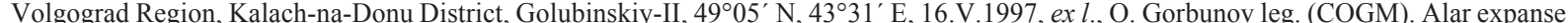
$17.5 \mathrm{~mm}$. Sesiidae pictures №№ 0333-0334-2017; 23-24 — paratype. Russia, Crimea, $2.8 \mathrm{~km} \mathrm{NW}$ of Kurskoye, Bor-Kaya, 45 $03.152^{\prime} \mathrm{N}$, 034 $55.154^{\prime} \mathrm{E}, 177 \mathrm{~m}, 08$.VII.2017, O. Gorbunov, K. Efetov leg. (COGM). Alar expanse $19.5 \mathrm{~mm}$. Sesiidae pictures №№ 0055-0056-2019.

Рис. 17-24. Изменчивость самцов Chamaesphecia efetovi sp.n.: 17-18 - голотип. Россия, Крым, 2.8 км С3 Курского, Бор-Кая, $45^{\circ} 03.152^{\prime}$ с.ш., $034^{\circ} 55.154^{\prime}$ в.д., 177 м, 07.VII.2016, О. Горбунов, К. Ефетов (COGM). Размах крыльев 17,1 мм. Sesiidae снимки №№

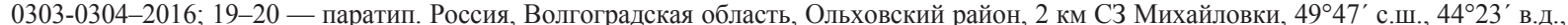
03-05.VI.2002, ex l., О. Горбунов (COGM). Размах крыльев 18,5 мм. Sesiidae снимки №№ 0331-0332-2017; 21-22 — паратип. Россия,

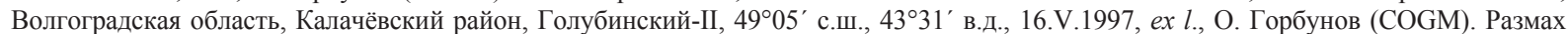
крыльев 17,5 мм. Sesiidae снимки №№ 0333-0334-2017; 23-24 — паратип. Россия, Крым, 2.8 км СЗ Курского, Бор-Кая, 450ㅜㅇ.152' с.ш., 03455.154' в.д., 177 м, 08.VII.2017, О. Горбунов, К. Ефетов (COGM). Размах крыльев 19,5 мм. Sesiidae снимки №№ 0055-0056-2019. 

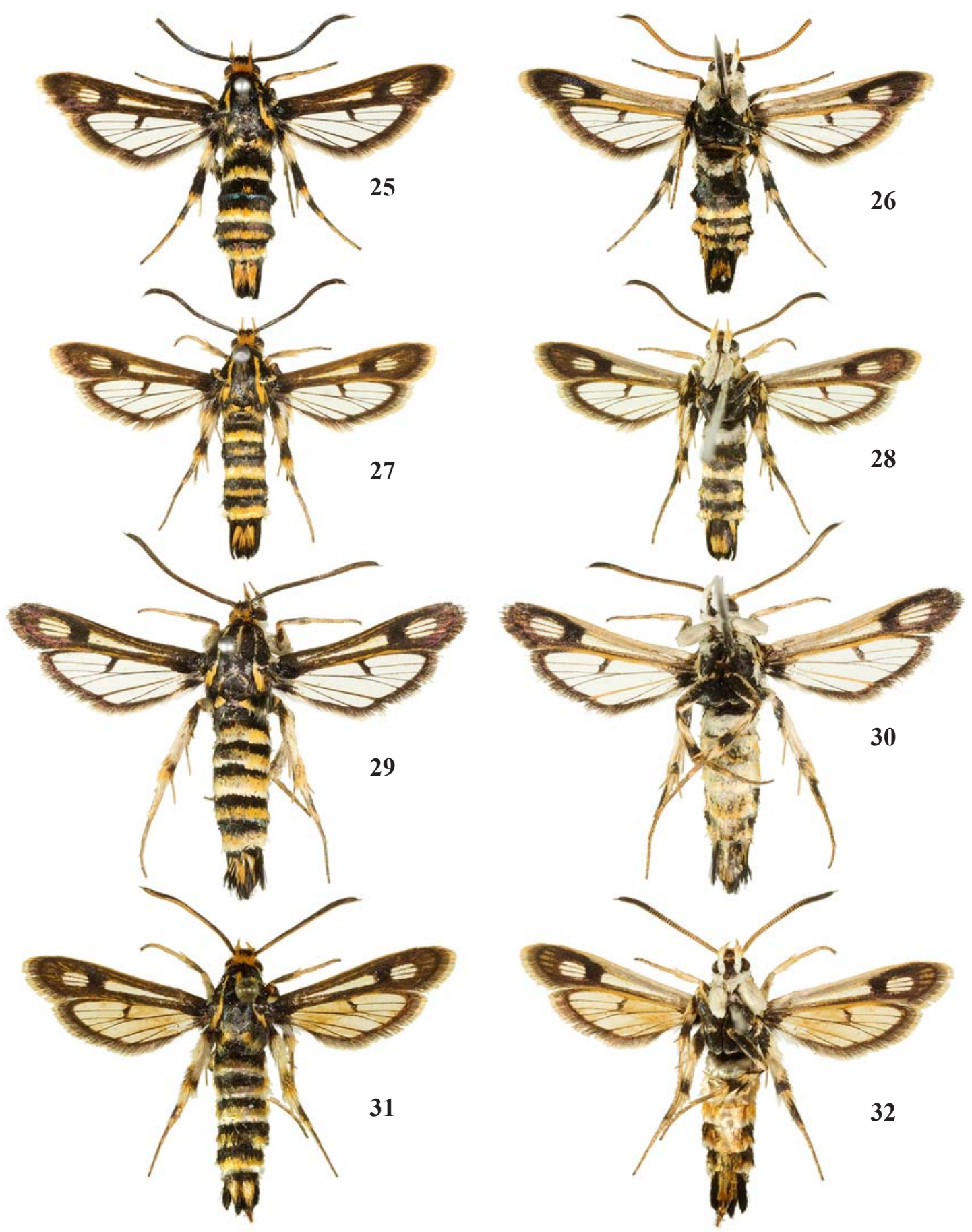

Figs 25-32. Variability of females of Chamaesphecia efetovi sp.n.: 25-26 - paratype. Russia, Crimea, Tarkhankut, Kipchak ravine,

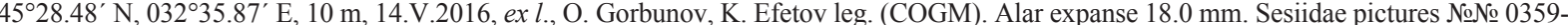
0360-2016; 27-28 - paratype. Russia, Volgograd Region, Ol'khovka District, 2 km NW of Mikhailovka, 4947' N, 44²3' E, 03-05.VI.2002, ex l., O. Gorbunov leg. (COGM). Alar expanse $16.8 \mathrm{~mm}$. Sesiidae pictures №№ 0327-0328-2017; 29-30 - paratype. Russia, Crimea, Arabatskaya Strelka, Solyanoye, $45^{\circ} 20.04^{\prime} \mathrm{N}, 035^{\circ} 24.05^{\prime}$ E, 0 m, 15.V.2018, ex l. O. Gorbunov, K. Efetov leg. (COGM). Alar expanse 20.0 mm. Sesiidae pictures №№ 0425-0426-2018; 31-32 - paratype. Russia, Volgograd Region, Ol'khovka District, 2 km NW of Mikhailovka,

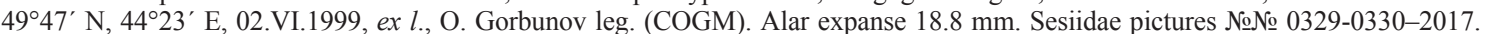

Рис. 25-32. Изменчивость самок Chamaesphecia efetovi sp.n.: 25-26 - паратип. Россия, Крым, Тарханкут, Балка Кипчак, 4528.48’ с.ш., 032 $35.87^{\prime}$ в.Д., 10 м, 14.V.2016, ex l., О. Горбунов, К. Ефетов (COGM). Размах крыльев 18,0 мм. Sesiidae снимки №№ 0359-03602016; 27-28 — paratype. Россия, Волгоградская область, Ольховский район, 2 км С3 Михайловки, 49²47’ с.ш., 44²3’' в.д., 03-05.VI.2002, ex l., О. Горбунов (COGM). Размах крыльев 16,8 мм. Sesiidae снимки №№ 0327-0328-2017; 29-30 - paratype. Россия, Крым, Арабатская Стрелка, Соляное, $45^{\circ} 20.04^{\prime}$ с.ш., 035²4.05' в.д., 0 м, 15.V.2018, ex l., О. Горбунов, К. Ефетов (COGM). Размах крыльев 20,0 мм. Sesiidae снимки №№ 0425-0426-2018; 31-32 — paratype. Россия, Волгоградская область, Ольховский район, 2 км С3 Михайловки, 4947’ с.ш., 44²3' в.д., 02.VI.1999, ex l., О. Горбунов (COGM). Размах крыльев 18,8 мм. Sesiidae снимки №№ 0329-0330-2017. 

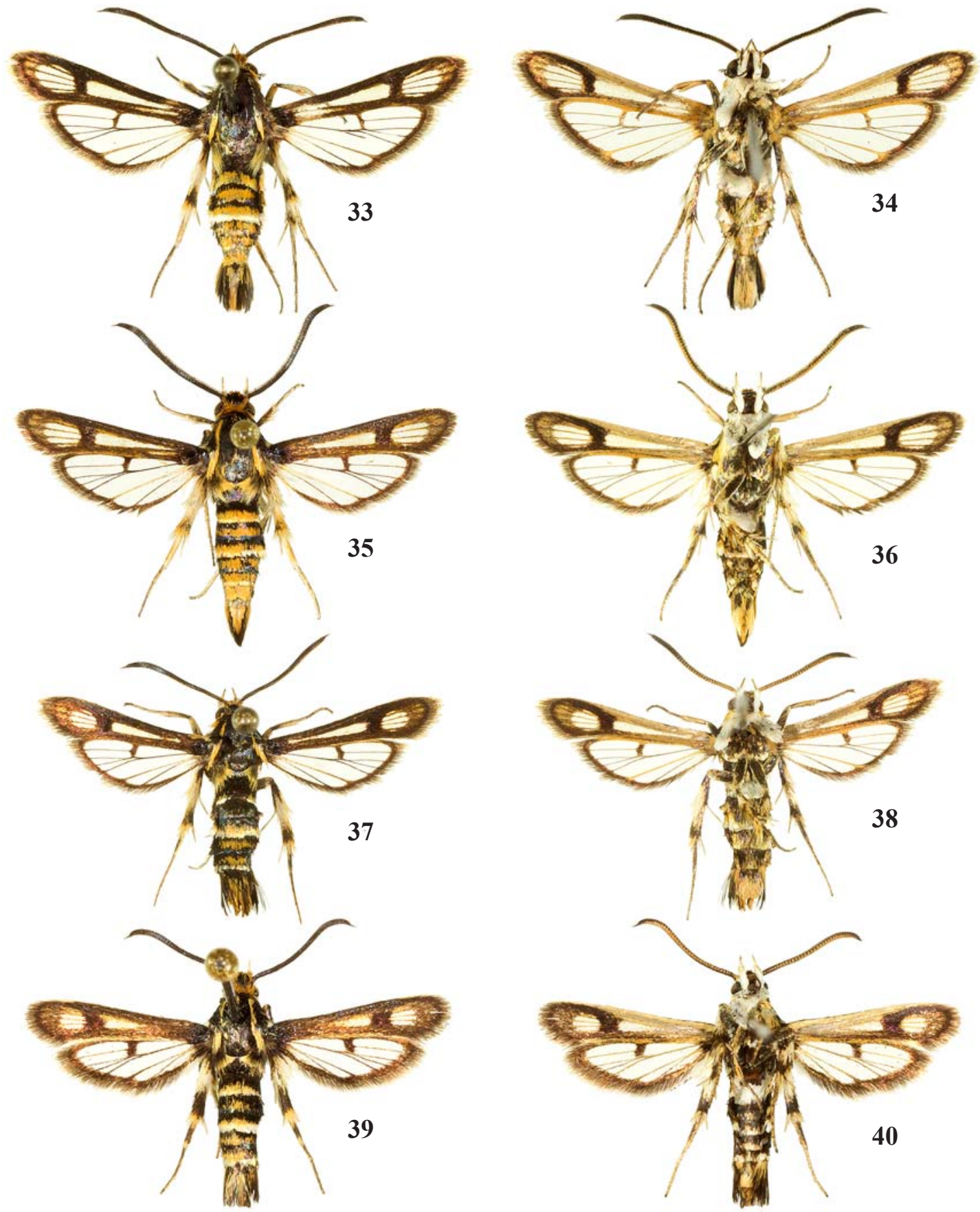

Figs 33-40. Variability of Chamaesphecia kalashiani sp.n.: 33-36 - males; 37-40 - females. 33-34 - holotype. Armenia, Vayots

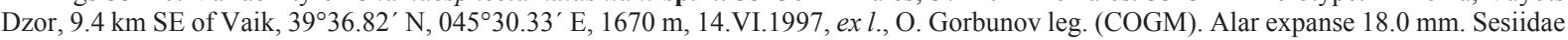

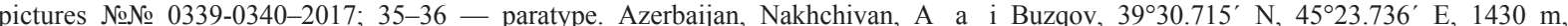
25.VI.1988, ex l., O. Gorbunov leg. (COGM). Alar expanse $17.3 \mathrm{~mm}$. Sesiidae pictures №№ 0335-0336-2017; 37-38 — paratype. Armenia,

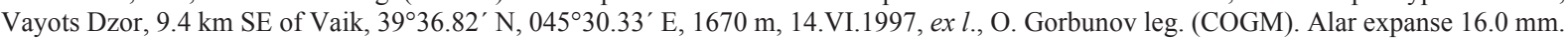

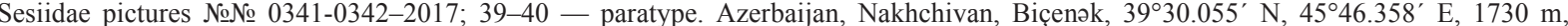
22.VII.1986, O. Gorbunov leg. (COGM); Alar expanse $17.0 \mathrm{~mm}$. Sesiidae pictures №№ 0337-0338-2017.

Рис. 33-40. Изменчивость Chamaesphecia kalashiani sp.n.: 33-36 - самшы; 37-40 - самки. 33-34 — голотип. Армения, Вайоцдзорская область, 9.4 км ЮВ Вайка, 39³6.82' с.ш., 045³0.33’ в.д., 1670 м, 14.VI.1997, ex l., О. Горбунов (COGM). Pазмах крыльев 18,0 мм. Sesiidae снимки №№ 0339-0340-2017; 35-36 - паратип. Азербайджан, Нахичевань, Верхний Бузгов, 39³0.715' с.ш., 45⒛736' в. Д., 1430 м, 25.VI.1988, ex l., О. Горбунов (COGM). Размах крыльев 17,3 мм. Sesiidae снимки №№ 0335-0336-2017; 37-38 - паратип. Армения, Вайоцдзорская область, 9.4 км ЮВ Вайка, 39³6.82' с.ш., 045³0.33’ в.д., 1670 м, 14.VI.1997, ex l., O. Горбунов (COGM). Размах крыльев 16,0 мм. Sesiidae снимки №№ 0341-0342-2017; 39-40 - паратип. Азербайджан, Нахичевань,

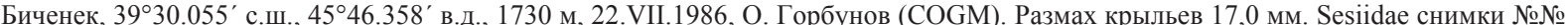
0337-0338-2017. 

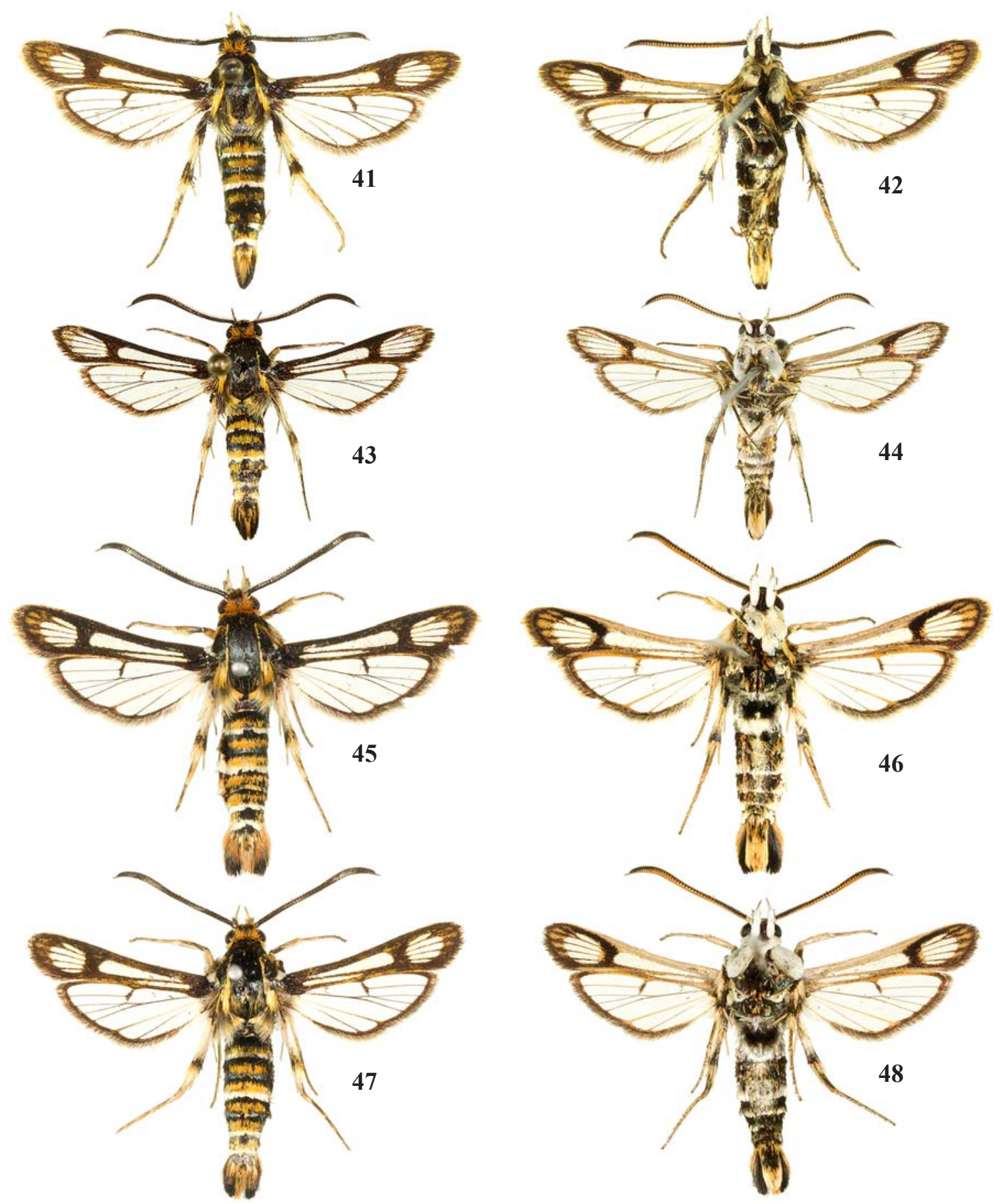

Figs 41-48. Variability of males of Chamaesphecia dumonti Le Cerf, 1922: 41-42 - Czechia, Moravia, Klentniče, 1984, ex l., Z. Laštůvka leg. (COGM). Alar expanse 18.5 mm. Sesiidae pictures №№ 0317-0318-2017; 43-44 — Russia, Volgograd Region, Novoannin-

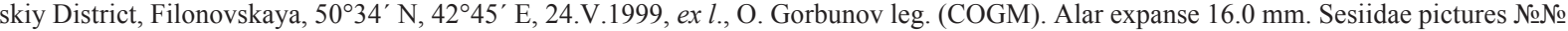
0319-0320-2017; 45-46 - Russia, Crimea, Kerch peninsula, Bagerovo, 45²3.014' N, 036 18.221’ E, 95 m, 17.V.2019, ex l., O. Gorbunov, K. Efetov leg. (COGM). Alar expanse $19.9 \mathrm{~mm}$. Sesiidae pictures №№ 0407-0408-2019; 47-48 - Ukraine, Crimea, Kerch peninsula,

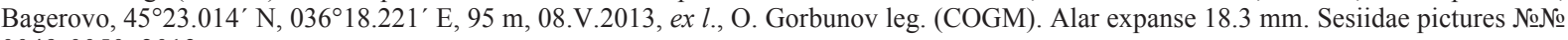
0049-0050-2013.

Рис. 41-48. Изменчивость самцов Chamaesphecia dumonti Le Cerf, 1922: 41-42 - Чехия, Моравия, Клентнице, 1984, ex l., 3. Лаштувка (COGM). Размах крыльев 18,5 мм. Sesiidae снимки №№ 0317-0318-2017; 43-44 - Россия, Волгоградская область,

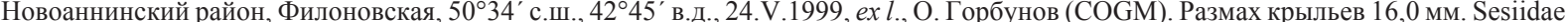
снимки №№ 0319-0320-2017; 45-46 - Россия, Крым, Керченский полуостров, Багерово, 45²3.014' с.ш., 036º $18.221^{\prime}$ в.д., 95 м, 17.V.2019, ex l., О. Горбунов, К. Ефетов (COGM). Размах крыльев 19,9 мм. Sesiidae снимки №№ 0407-0408-2019; 47-48 — Украина,

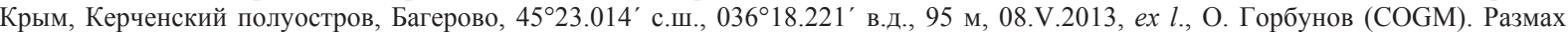
крыльев 18,3 мм. Sesiidae снимки №№ 0049-0050-2013. 

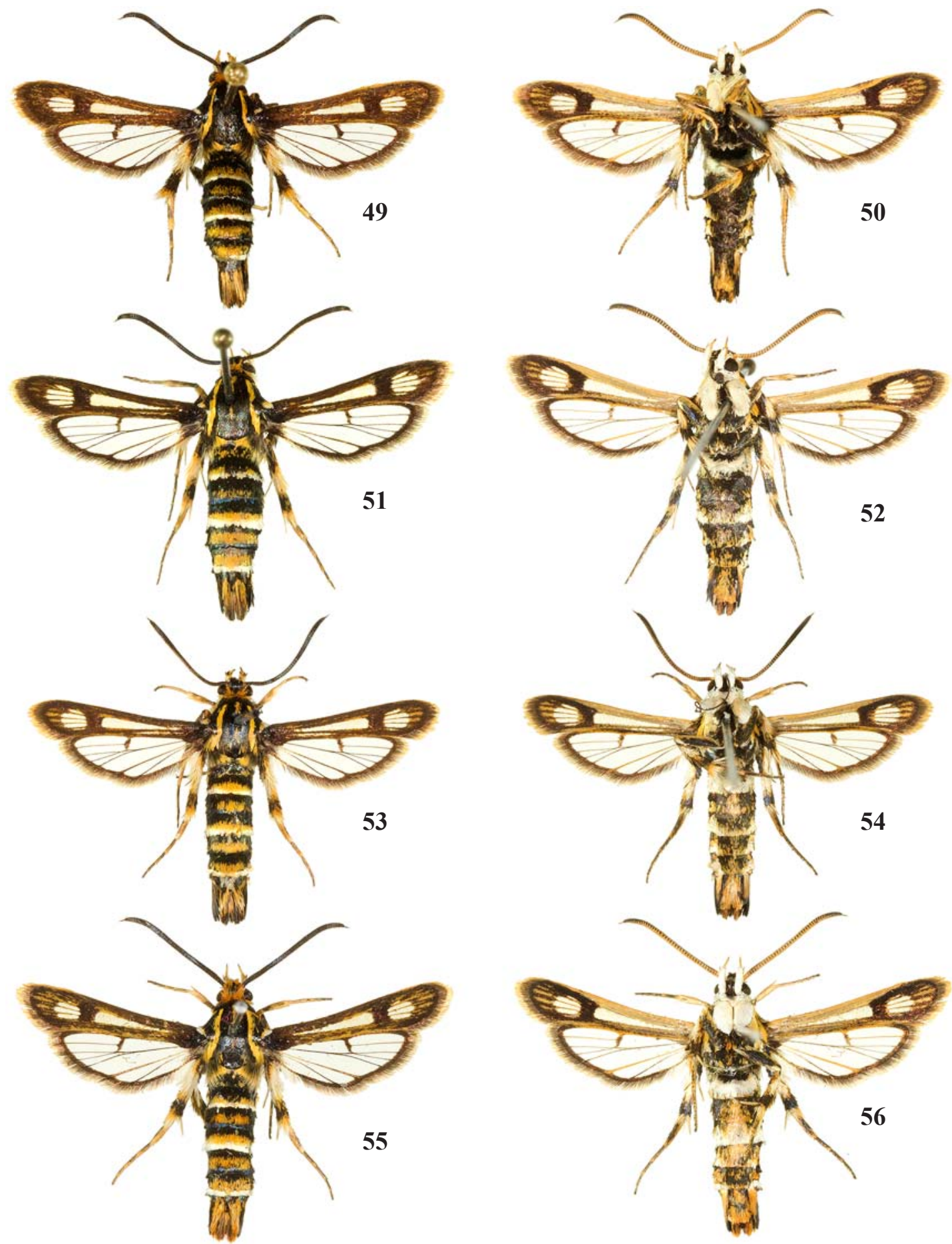

Figs 49-56. Variability of females of Chamaesphecia dumonti Le Cerf, 1922: 49-50 - Czechia, Moravia, Klentniče, 1984, ex l., Z. Laštůvka leg. (COGM). Alar expanse $19.5 \mathrm{~mm}$. Sesiidae pictures №№ 0321-0322-2017; 51-52 — Russia, Ulianovsk Region, $4 \mathrm{~km} \mathrm{E} \mathrm{of}$ Ryabina, 52 ${ }^{\circ} 55^{\prime} \mathrm{N}, 048^{\circ} 21^{\prime}$ E, 9.VI.1998, ex l., O. Gorbunov leg. (COGM). Alar expanse $20.0 \mathrm{~mm}$. Sesiidae pictures №.№ 0323-0324-2017; 53-54 - Russia, Volgograd, 48 $37^{\prime} \mathrm{N}, 04^{\circ} 23^{\prime}$ E, 30.VI.1998, ex l., O. Gorbunov leg. (COGM). Alar expanse $18.6 \mathrm{~mm}$. Sesiidae pictures

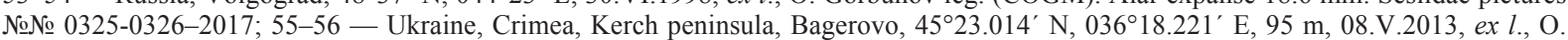
Gorbunov leg. (COGM). Alar expanse $19.8 \mathrm{~mm}$. Sesiidae pictures №№ 0041-0042-2013.

Рис. 49-56. Изменчивость самок Chamaesphecia dumonti Le Cerf, 1922: 49-50 - Чехия, Моравия, Клентнице, 1984, ex l., 3. Лаштувка (COGM). Размах крыльев 19.5 мм. Sesiidae снимки №№ 0321-0322-2017; 51-52 — Россия, Ульяновская область, 4 км В Рябины, 52 $55^{\prime}$ с.ш., 048²1' в.д., 9.VI.1998, ex l., О. Горбунов (COGM). Размах крыльев 20.0 мм. Sesiidae снимки №№ 0323-0324-

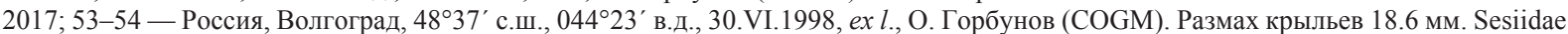
снимки №№ 0325-0326-2017; 55-56 - Украина, Крым, Керченский полуостров, Багерово, 45ํ23.014’ с.ш., 036 18.221' в.д., 95 м, 08.V.2013, ex l., О. Горбунов (COGM). Размах крыльев 19.8 мм. Sesiidae снимки №№ 0041-0042-2013. 
longitudinal orange spot subdistally; ventrally sternite $1+2$ pale yellow with golden hue with a few black scales medially; sternites 3-7 each with a broad pale yellow with golden hue stripe distally; anal tuft orange with an admicture of black scales laterally.

Male genitalia (Figs 57-60). Genital preparation № OG-023-2018.

Female (Figs 9-10) (Sesiidae pictures №№ 0313-0314 2017). Alar expanse $22.0 \mathrm{~mm}$, body length $12.9 \mathrm{~mm}$, forewing $9.8 \mathrm{~mm}$, antenna $6.3 \mathrm{~mm}$. Noticeably more robust than male.

Head with antenna and scapus orange-yellow ventrally; frons white to pale yellow-orange with golden-purple hue and a few dark gray-brown scales medially; labial palpus white in basal half and yellow-orange in apical half; vertex orange with a few black scales.

Thorax with patagia with yellow-orange scales anteriorly; tegula with a broader orange inner margin. Legs with fore coxa white with golden hue and a few yellow-orange scales with golden hue externally at base; fore femur externally yellow-orange with golden hue and a few dark gray-brown scales medially; mid and hind coxae black with dark greenish-blue sheen with a few orange scales posteriorly; hind tarsus with dark gray-brown scales externally. Forewing with transparent areas smaller, posterior transparent area very short, not reaching level of cross-vein of hindwing; external transparent area smaller, divided into three cells between veins $R_{4+5}$ and $M_{3}$, level to vein $M_{2}$ about 1.3 times as broad as discal spot and slightly broader than apical area.

Abdomen dorsally with only tergites 4 and 6 each with white to pale yellow with golden hue stripe distally; all sternites covered with orange scales.

Otherwise colour pattern as in male.

Female genitalia (Fig. 73). Genital preparation № OG024-2018.

INDIVIDUAL VARIABILITY. Both males (Figs 1-8) and females (Figs 9-16) vary in the number of orange, yelloworange, yellow or pale yellow scales on the head, thorax, legs and abdomen. Scales on distal margin of tergites 2, 4, 6 and 7 in males and 1, 4 and 6 in females vary from white to pale

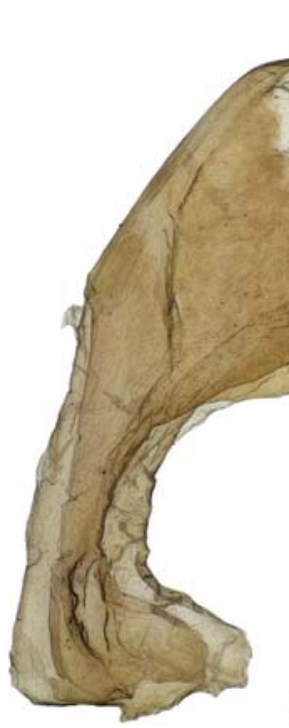

57
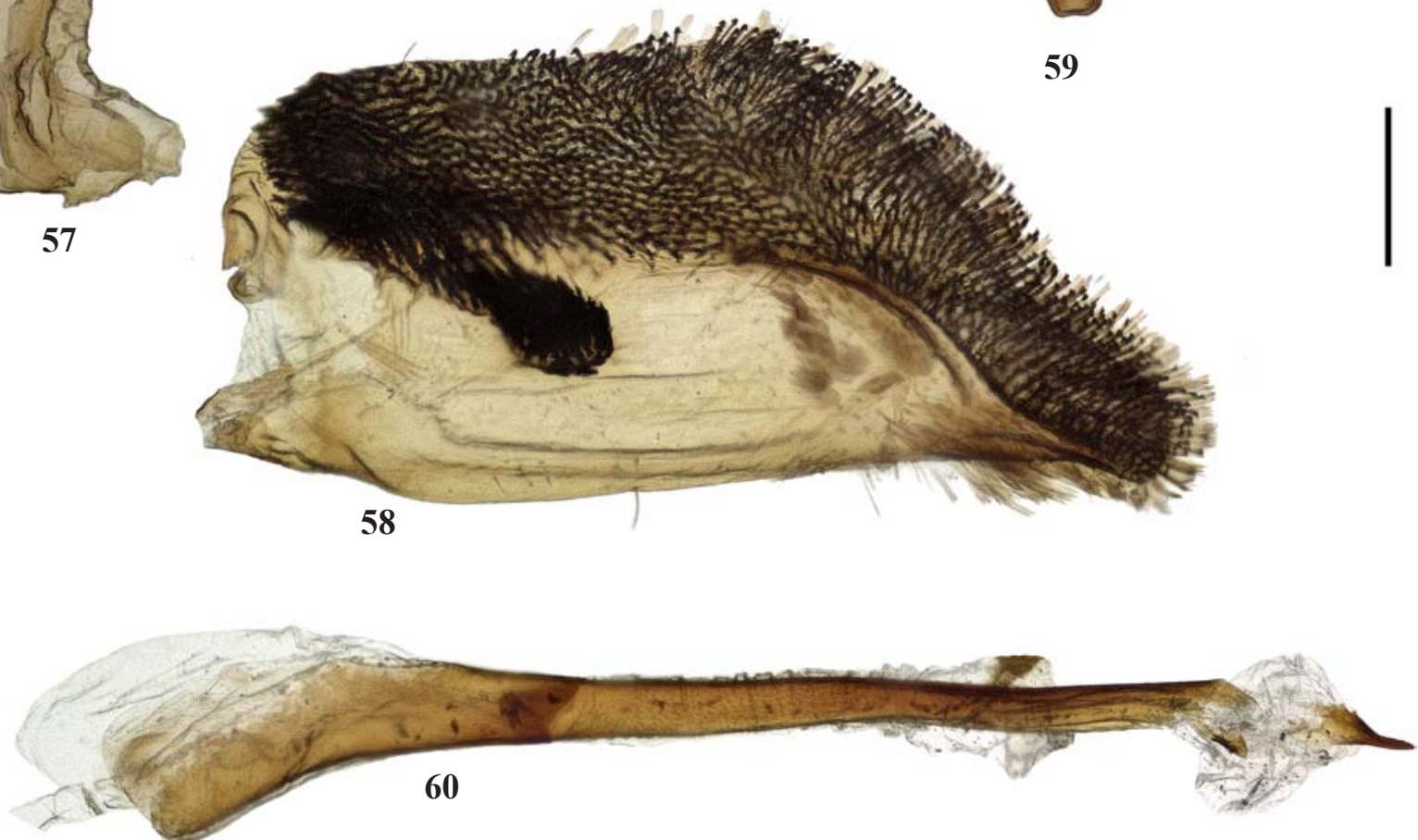

Figs 57-60. Male genitalia of Chamaesphecia oxybeliformis (Herrich-Schäffer, 1846), genital preparation № OG-023-2018: 57 tegumen-uncus complex; 58 - valva; 59 - saccus; 60 - aedeagus. Scale bar $0.5 \mathrm{~mm}$.

Рис. 57-60. Гениталии самца Chamaesphecia oxybeliformis (Herrich-Schäffer, 1846), препарат гениталий № OG-023-2018: 57 тегумен-ункус комплекс; 58 - вальва; 59 - саккус; 60 - эдеагус. Масштаб 0,5 мм. 
yellow with bright golden hue. The colouration of the flying and not very fresh specimens is much paler and with less number of orange or orange-yellow scales on the thorax and abdomen. In addition, such specimens are deprived of a large number of yellow-orange to orange scales masking the background colouration of the forewings. Individual size is variable as follows. Males: alar expanse 19.0-22.0 mm, body length $11.0-12.0 \mathrm{~mm}$, forewing $8.3-9.6 \mathrm{~mm}$, antenna $5.6-5.9 \mathrm{~mm}$. Females: alar expanse 17.0-22.0 mm, body length 10.2-12.9 $\mathrm{mm}$, forewing 7.6-9.8 mm, antenna $6.0-6.3 \mathrm{~mm}$.

DIFFERENTIAL DIAGNOSIS. Ch. oxybeliformis, Ch. djakonovi and Ch. ophimontana form a separate and compact group. Phylogenetically this group is very closely related to Ch. annellata species-group, but, unlike it, the species of $C h$. oxybeliformis species-group differ quite well from each other in the colour of various parts of the body and wings. Characteristic features of this subgroup are their trophic specialization (their caterpillars feed on the roots of Phlomis herbaventi), allopatric distribution, and, as the Ch. annellata species-group as a whole, almost complete absence of morphological differences in the genitalia of both males and females.

Ch. oxybeliformis differs from Ch. djakonovi (type locality: Russia, Crimea, Kara Dag) by the colouration of the frons (grey-brown with greenish-bronze sheen and a broad white stripe laterally in male and white to pale yellow-orange with golden-purple hue and a few dark gray-brown scales medially in female of Ch. oxybeliformis, vs. dark brown to black with anthracite sheen and a narrow white stripe laterally in $C h$ djakonovi) and noticeably fewer black scales on the vertex, and by the colouration of the forewing (costal and anal margins, $\mathrm{CuA}$-stem and apical area dark brown with bronze-violet sheen, but densely covered with orange to yellow-orange scales masking background colouration in Ch. oxybeliformis, vs. costal and anal margins, $\mathrm{CuA}$-stem and apical area dark brown with bronze-violet sheen with a few yellow-orange to yellow-orange and light brown scales in Ch. djakonovi). In general, Ch. djakonovi is darker, with more black scales on the legs and abdomen and bright scales are more yellow (cp. Figs 1-16 with figs 19 and 20 in Gorbunov, 2013).

From Ch. ophimontana (type locality: Azerbaijan, Nakhchivan, A a i Buzqov) Ch. oxybeliformis can be distinguished by the colouration of the vertex (vertex orange with an admixture of black scales with greenish sheen medially in male and orange with a few black scales in female of $C h$. oxybeliformis vs. black with a few orange scales anteriorly in Ch. ophimontana). In addition, in Ch. ophimontana all bright scales on the thorax, legs, wings and abdomen not orange or yellow-orange, but lemon-yellow.

From all other species of the Ch. annellata speciesgroup, including those that can be found in habitats of $C h$. oxybeliformis or nearby, namely $C h$. annellata, Ch. dumont and Ch. efetovi sp.n., Ch. oxybeliformis is clearly distinguished by the bright orange or orange-yellow colouration of thorax, legs, wings and abdomen (scales on the thorax, legs, wings and abdomen, yellow or yellow-orange in all these species compared).

BIONOMICS. The larval host-plant is Phlomis herbaventi ssp. pungens (Willd.) Maire ex DeFilipps (Lamiaceae). The larva lives in the root where it bores a tunnel about 5-9 $\mathrm{cm}$ long. It lives during a year and pupates in a cocoon in the upper part of the tunnel. Moths on the wings from the mid June to the mid July. They can be found sitting on (Figs 7778 ) or flying between the host-plants. I have never managed to attract males to artificial sex attractant lures.

HABITAT. Various types of herbaceous steppes with the obligatory presence of the host plant.
DISTRIBUTION. Currently, this species is known to occur in the steppe zone from the left bank of the Dnieper River in the west to north-western Kazakhstan in the east, to the north of the Volgograd region in the north and the Crimean steppe in the south.

\section{Chamaesphecia (Scopulosphecia) efetovi O. Gorbunov, sp.n.}

Figs $17-32,61-64,74,79,80$.

Chamaesphecia oxybeliformis auct. nec Chamaesphecia oxybeliformis (Herrich-Schäffer, 1846)

LITERATURE. Popesku-Gorj et al., 1958: 135 (Chamaesphecia annellata f. oxybeliformis); Laštůvka, 1983: 199, 201 figs 3, 8 (Chamaesphecia oxybeliformis); Laštůvka, 1990a: 102 (Chamaesphecia oxybeliformis); Laštůvka, 1990b: 470 (Chamaesphecia oxybeliformis); Śpatenka et al., 1999: 362 (Chamaesphecia oxybeliformis; part.)

MATERIAL. Holotype $\sigma^{7}$ (Figs 17-18) with labels: "Russia,

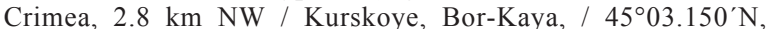
034 55.186'E, / 177 m, 07.VII.2016, / O. Gorbunov \& K. Efetov leg." (white); "SESIIDAE / Pictures №№ / 0303-0304-2016 / Photo by O. Gorbunov" (white); "HOLOTYPUS $\sigma^{7} /$ Chamaesphecia efetovi / O. Gorbunov, 2019 / O. Gorbunov des., 2017” (red) (COGM).

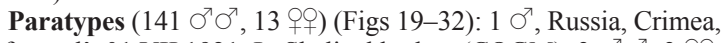
Simferopol', 01.VII.1921, L. Sheljuzhko leg. (COGM); $3 \sigma^{\top} \sigma^{\top}, 3$, 3 , same locality, 03.VII.1921, L. Sheljuzhko leg. (1 + with genitalia preparation № OG-049-2018) (COGM); 2 O $^{7}$ (Figs 21-22), 1 우, Russia, Volgograd Region, Kalach-na-Donu District, Golubinskiy-II, $49^{\circ} 05^{\prime} \mathrm{N}, 043^{\circ} 31^{\prime} \mathrm{E}, 16 . \mathrm{V} .1997$, ex larvae from roots of Marrubium praecox (Lamiaceae), moths emerged 01-04.VII.1997, O. Gorbunov leg. (Sesiidae pictures №№ 0333-0334-2017) (COGM); 2 ○ $^{7}$, Russia Stavropol' Region, Essentuki District, Belyi Ugol', 19.VII.1997, O. Gorbunov leg. (COGM); $2 \sigma^{7} \sigma^{7}, 1$ (Figs 31-32), Russia, Volgograd Region, Ol'khovka District, 2 km NW of Mikhailovka, $49^{\circ} 47^{\prime} \mathrm{N}$, $44^{\circ} 23^{\prime} \mathrm{E}, 02$.VI.1999, ex larvae from roots of Marrubium praecox (Lamiaceae), moths emerged 03-04.VII.1999, O. Gorbunov leg. (Sesiidae pictures №№ 0329-0330-2017) (COGM); 1 O $^{7}$ (Figs 19-20), 1 +, (Figs 27-28) same locality, 03-05.VI.2002, ex larvae from roots of Marrubium praecox (Lamiaceae), moths emerged 04.VII.2002, O. Gorbunov leg. (Sesiidae pictures №№ 0327-0328-2017) (COGM); 9 $\sigma^{\top} \sigma^{\top}$, Ukraine, Crimea, $2.8 \mathrm{~km} \mathrm{NW}$ of Kurskoye, Bor-Kaya, $45^{\circ} 03.150^{\prime} \mathrm{N}, 034^{\circ} 55.186^{\prime} \mathrm{E}, 177 \mathrm{~m}$, 12.VII.2013, O. Gorbunov \& K. Efetov leg. (Sesiidae pictures №oo 0495-0502-2019) (COGM); 19 $\sigma^{7} \sigma^{7}$, Ukraine, Crimea, Simferopol', Dubki, 445․009'N, $034^{\circ} 02.064^{\prime} \mathrm{E}, 304 \mathrm{~m}, 10 . \mathrm{VII} .2013$, O. Gorbunov leg. (Sesiidae pictures №№ 0079-0086-2013, 0089-0090-2013, 0105-0108-2013, 0111-0114-2013, 0199-0204-2013, 0205-0206-2013) (1 or with genitalia preparation № OG-041-2018) (COGM); 7 O $\sigma^{7}$, Ukraine, Crimea, $2.8 \mathrm{~km} \mathrm{NW}$ of Kurskoye, Bor-Kaya, $45^{\circ} 03.150^{\prime} \mathrm{N}$, 034 $55.186^{\prime} \mathrm{E}, 177$ m., 12.VII.2013, O. Gorbunov \& K. Efetov leg. (Sesiidae pictures №№ 0109-0110-2013, 0115-0120-2013, 01210126-2013, 0129-0130-2013) (1 $\sigma^{7}$ with OGGS028) (COGM); 5 $\sigma^{7} \sigma^{7}$, same locality, 18.VII.2013, K. Efetov leg. (CKES); $1 \bigcirc^{7}$ same locality, 21.VII.2013, K. Efetov leg. (CKES); $7 \sigma^{7} \sigma^{7}$, Russia, Crimea, $2.8 \mathrm{~km}$ NW of Kurskoye, Bor-Kaya, $45^{\circ} 03.150^{\prime} \mathrm{N}, 034^{\circ} 55.186^{\prime} \mathrm{E}$, 177 m., 27.VII.2014, K. Efetov leg. (CKES); $14 \sigma^{7} \sigma^{7}$, same locality, 15.VII.2015, K. Efetov leg. (CKES); 1 フ , Russia, Volgograd Region, Ol'khovka District, $2 \mathrm{~km}$ NW of Mikhailovka, 49 $47^{\prime} \mathrm{N}, 4^{\circ} 23^{\prime} \mathrm{E}$, 08.VII.2015, O. Gorbunov leg. (Sesiidae pictures №№ 0397-03982015) (COGM); 1 , same locality, 12.V.2016, ex larva from a root of Marrubium peregrinum (Lamiaceae), moth emerged 03.VII.2016, O. Gorbunov leg. (Sesiidae pictures №№ 0361-0362-2016) (COGM); $2 \sigma^{\top} \sigma^{7}, 1$ (Figs 25-26), Russia, Crimea, Tarkhankut, Kipchak ravine, $45^{\circ} 28.48^{\prime} \mathrm{N}, 032^{\circ} 35.87^{\prime} \mathrm{E}, 10 \mathrm{~m}, 14 . \mathrm{V} .2016$, ex larvae from roots of Marrubium peregrinum (Lamiaceae), moths emerged 27 and 29.VI.2016, O. Gorbunov \& K. Efetov leg. (Sesiidae pictures №№ 0357-0360-2016, 0407-0408-2016) (COGM); 9 フ ○ా, Russia, Crimea, $2.8 \mathrm{~km} \mathrm{NW}$ of Kurskoye, Bor-Kaya, $45^{\circ} 03.150^{\prime} \mathrm{N}$, 034 $55.186^{\prime} \mathrm{E}, 177$ m., 07.VII.2016, O. Gorbunov \& K. Efetov leg. (Sesiidae pictures №№ 0301-0302-2016, 0307-0310-2016) (COGM); $2 \bigcirc^{\top} \sigma^{\top}$, Russia, Crimea, Simferopol', Bitak, 4456.760'N, 
03408.803'E, $331 \mathrm{~m}, 12 . \mathrm{VII} .2016$, O. Gorbunov \& K. Efetov leg. (COGM); 3 o $\sigma^{7}$, Russia, Crimea, Belogorsk, $6.3 \mathrm{~km} \mathrm{NW}$ of Belogorsk, Sary-Kaya, $45^{\circ} 06.007^{\prime}$ N, 034³3.024’E, 243 m, 12.VII.2016, O Gorbunov \& K. Efetov leg. (COGM); 7 ○ $\sigma^{7}$ (Figs 23-24), Russia, Crimea, 2,8 km NW of Kurskoye, Bor-Kaya, $45^{\circ} 03.150^{\prime} \mathrm{N}$, 034 $55.186^{\prime} \mathrm{E}, 177$ m., 08.VII.2017, O. Gorbunov \& K. Efetov leg. (Sesiidae pictures №№ 0275-0276-2017, 0047-0056-2019, 0057 0058-2019) (COGM); 1 (Figs 29-30), Russia, Crimea, Arabatskaya Strelka, Solyanoye, $45^{\circ} 20.04^{\prime} \mathrm{N}, 035^{\circ} 24.05^{\prime} \mathrm{E}, 0 \mathrm{~m}, 15 . \mathrm{V} .2018$, ex larva from a root of Marrubium peregrinum (Lamiaceae), moth emerged 20.VI.2018, O. Gorbunov \& K. Efetov leg. (Sesiidae pictures №oo 0425-0426-2018) (COGM); 5 ○ $^{7}$, Russia, Crimea, Kirovskoye District, Novofyodorovka, $45^{\circ} 17.412^{\prime} \mathrm{N}, 035^{\circ} 03.554^{\prime} \mathrm{E}, 24 \mathrm{~m}$, 14.VII.2019, O. Gorbunov \& K. Efetov, M. Efetov leg. (Sesiidae pictures №№ 0369-0378-2019) (COGM); $4 \sigma^{\top} \sigma^{7}$, same locality and date, O. Gorbunov \& K. Efetov leg. (CKES); $3 \sigma^{\top} \sigma^{\top}, 1$, 1 , Russia, Crimea, Sovetskoye District, Razdolnoye, $45^{\circ} 21.992^{\prime} \mathrm{N}$, 034 $51.487^{\prime} \mathrm{E}, 19 \mathrm{~m}, 14 . \mathrm{VII} .2019$, O. Gorbunov, K. Efetov \& M Efetov leg. (Sesiidae pictures №№ 0379-0384-2019) (COGM); 7 $\sigma^{7} \sigma^{7}, 1$, Russia, Crimea, Belogorsk District, Karasyovka,

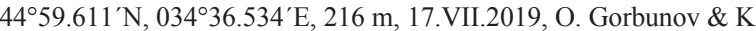
Efetov leg. (COGM); 5 ○ $\sigma^{7}$, Russia, Crimea, Belogorsk District, 1.5 $\mathrm{km}$ SW of Golovanovka, 44 $58.050^{\prime} \mathrm{N}, 034^{\circ} 36.666^{\prime} \mathrm{E}, 324 \mathrm{~m}$ 17.VII.2019, O. Gorbunov \& K. Efetov leg. (Sesiidae pictures №№ 0361-0368-2019) (COGM); 3 O $^{\top}, 1$, Russia, Crimea, Arabatskaya Strelka, $45^{\circ} 18.008^{\prime} \mathrm{N}, 035^{\circ} 28.154^{\prime} \mathrm{E}, 1 \mathrm{~m}, 18$.VII.2019, O. Gorbunov \& K. Efetov leg. (Sesiidae pictures №№ 0397-0398-2019, 0403 0404-2019) (COGM); 2 O $^{7}$, Russia, Crimea, Belogorsk District, 5 $\mathrm{km} \mathrm{W}$ of Belogorsk, $45^{\circ} 03.911^{\prime} \mathrm{N}, 034^{\circ} 30.148^{\prime} \mathrm{E}, 303 \mathrm{~m}, 19 . \mathrm{VII} .2019$ O. Gorbunov \& K. Efetov leg. (Sesiidae pictures №№ 0359-03602019) (COGM); $3 \sigma^{7} \sigma^{7}$, Russia, Crimea, Sevastopol', Generala Zhi-

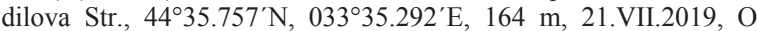
Gorbunov \& K. Efetov leg. (Sesiidae pictures №№ 0385-0390-2019) (COGM); $1 \sigma^{7}$, Russia, Crimea, Belogorsk District, $2 \mathrm{~km} \mathrm{SW}$ of Zybiny, $45^{\circ} 13.223^{\prime} \mathrm{N}, 034^{\circ} 38.005^{\prime} \mathrm{E}, 90 \mathrm{~m}, 22$. VII.2019, O. Gorbunov \& K. Efetov leg. (COGM); $8 \sigma^{\top} \sigma^{\top}, 1$ ㅇ, Russia, Crimea,

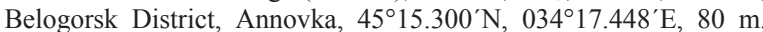
22.VII.2019, O. Gorbunov \& K. Efetov leg. (Sesiidae pictures №№ 0391-0394-2019, 485-490-2019) (COGM); $2 \sigma^{7} \sigma^{7}, 1$ ㅇ, same locality and date, O. Gorbunov \& K. Efetov leg. (CKES); $1 \sigma^{7}$, Russia Crimea, Belogorsk District, Turgenevo, $45^{\circ} 13.467^{\prime} \mathrm{N}, 034^{\circ} 15.340^{\prime} \mathrm{E}$, 85 m, 22.VII.2019, O. Gorbunov \& K. Efetov leg. (Sesiidae pictures №№ 0395-0396-2019) (COGM).

DESCRIPTION. Male (holotype) (Figs 17-18) (Sesiidae pictures №№ 0303-0304-2016). Alar expanse $17.1 \mathrm{~mm}$, body length $10.5 \mathrm{~mm}$, forewing $7.6 \mathrm{~mm}$, antenna $5.2 \mathrm{~mm}$.

Head with antenna dark brown with bronze sheen dorsally and yellow with golden hue ventrally, scapus black dorsally and pale yellow ventrally; frons gray-brown with purple sheen and a narrow white stripe laterally; basal joint of labial palpus white, mid joint white with a narrow black stripe exterior-ventrally and pale yellow scales interior-dorsally, apical joint pale yellow; vertex black with dark violet sheen and a few yellow-orange scales both anteriorly and laterally; pericephalic hairs yellow-orange dorsally and white laterally.

Thorax with patagia dark brown to black with bronzepurple sheen; tegula dark brown to black with greenishpurple sheen, with narrow yellow inner margin and a small white to pale yellowish spot at base of forewing anteriorly; mesothorax dark brown to black with greenish-purple sheen, with a narrow yellow stripe anterior-medially and a few yellow scales posteriorly; metathorax yellow with a tuft of pale yellow hair-like scales laterally; thorax laterally darkgray brown with greenish-violet sheen and a large pale yellow to white spot; posteriorly metepimeron dark gray-brown, metameron white, both of them covered with white hair-like scales. Legs with neck plate white; fore coxa white with a dark gray spot medially; fore femur pale yellow with golden sheen; fore tibia pale yellow with a few gray-brown scales dorsally; fore tarsus entirely pale yellow with golden sheen; mid coxa black with dark blue-violet sheen; mid femur internally pale yellow, externally black with dark blue-violet sheen and a dense admixture of pale yellow to white scales anterior-distally; mid tibia pale yellow to white with a large black spot with dark blue-violet sheen exterior-distally; spurs pale yellow with golden hue; mid tarsus pale yellow with golden sheen; hind coxa black with dark blue-violet sheen; hind femur internally pale yellow, externally black with dark blue-violet sheen and a dense admixture of pale yellow to white scales anterior-distally; hind tibia white with a broad black ring with dark blue-violet sheen both basally and at base of apical spurs and with a few yellow scales at margins of black rings; spurs pale yellow with golden hue; basal hind tarsomere pale yellow to white with a longitudinal black spot with dark blue-violet sheen externally, remaining tarsomeres entirely pale yellow with golden sheen. Forewing dorsally black at base; costal and anal margins, CuA-stem, veins within external transparent area and apical area brown with golden sheen and an admixture of individual yellowish scales; discal spot somewhat darker; transparent area well-developed, but posterior transparent area short and not reaching level of cross-vein of hindwing; external transparent area rather large with rounded distal margin, divided into four cells between veins $R_{3}$ and $M_{3}$, level to vein $M_{2}$ about 1.75 times as broad as discal spot and apical area; ventrally costal and anal margins and basal half of $\mathrm{CuA}$-stem pale yellow, remaining opaque parts dark brown to black with dark blueviolet sheen and with an admixture of individual pale yellow scales on apical area; veins within external transparent area pale yellow; cilia dark brown basally and white distally. Hindwing transparent; dorsally veins, discal spot and outer margin dark brown with dark purple sheen; discal spot trapeziform, relatively broad, reaching base of veins $\mathrm{M}_{3}-\mathrm{CuA}$; outer margin narrow about 0.5 as broad as cilia; ventrally veins pale yellow to yellow; discal spot and outer margin dark brown with dark violet sheen; cilia dark brown basally and white distally.

Abdomen dorsally black with dark greenish-violet sheen; tergites 2, 4, 6 and 7 each with a narrow white stripe with golden hue distally; tergites 2, 4-7 each with a narrow yellow stripe subdistally; tergite 3 with a short and narrow yellow strip subdistally; ventrally sternite $1+2$ white with a few black scales basally; sternite 4 with a narrow pale yellow to white stripe distally; sternites 5-7 each with pale yellow to white scales distally; anal tuft black with dark greenish sheen laterally and pale yellow both laterally and ventrally.

Male genitalia (Figs 61-64). Paratype. Genital preparation № OG-041-2018.

Female (paratype) (Figs 25-26) (Sesiidae pictures №№ 0359-0360-2016). Alar expanse $18.0 \mathrm{~mm}$, body length 10.8 $\mathrm{mm}$, forewing $8.2 \mathrm{~mm}$, antenna $4.9 \mathrm{~mm}$. Noticeably more robust than male.

Head with antenna yellow-orange ventrally; frons with a narrow pale yellow stripe laterally; mid joint of labial palpus white with yellow-orange scales externally in distal half, apical joint yellow-orange with a few brown scales distally; vertex orange posteriorly and black anteriorly; pericephalic hairs orange dorsally.

Thorax dorsally with brighter yellow scales, laterally with yellow-orange scales and posteriorly metepimeron with brown hair-like scales. Legs with fore coxa entirely white; fore femur yellow with golden sheen and black scales with blue-violet sheen externally; fore tarsus yellow-orange with golden sheen ventrally and bark brown with bronze-green sheen dorsally; mid tibia black with dark greenish-blue sheen and a large yellow to yellow-orange spot exterior-medially, 
with a few yellow-orange longitudinal scales dorso-distally and a few white scales interior-basally; spurs yellow-orange with golden hue; mid tarsus yellow-orange with golden sheen ventrally, dorsally dark brown with bronze-violet sheen and a small yellow-orange spot distally on two basal tarsomeres; hind tibia pale yellow with a broad black ring with dark blueviolet sheen both basally and at base of apical spurs and with a few yellow-orange scales at margins of black rings; spurs yellow-orange with golden hue; hind tarsus yellow-orange ventrally, dorsally basal tarsomere black with blue-violet sheen and a small yellow-orange spot distally, remaining tarsomeres dark brown with bronze-violet sheen. Forewing with less developed transparent areas, posterior transparent area undeveloped, external transparent area small, oval, divided into three cells between veins $R_{4+5}$ and $M_{3}$, level to vein $\mathrm{M}_{2}$ about as broad as discal spot and apical area; cilia dark brown basally and yellow distally. Discal spot of hind wing somewhat broader and cilia with yellow distally.

Abdomen dorsally with tergites 2, 4 and 6 each with a narrow pale yellow stripe distally; tergites 2, 4-6 each with a narrow yellow stripe subdistally; ventrally sternites $4-6$ each with a narrow yellow stripe distally; dorsally anal tuft black with yellow-orange scales medially.

Otherwise colour pattern as in male (holotype).

Female genitalia (Fig. 74). Paratype. Genital preparation № OG-049-2018.

INDIVIDUAL VARIABILITY. Males of this new species have two colour forms. They are not clearly delineated, but one is lighter, like the holotype described above (Figs 17-18), and the other is more yellow (Figs 19-22). Yellow specimens are much less common. Among paratypes there are no more than $10 \%$ of them. There is a male (Figs 23-24), in which tergites 2-7 each with a broad yellow stripe and abdomen ventrally practically entirely pale yellow. Females (Figs 25-32) vary in

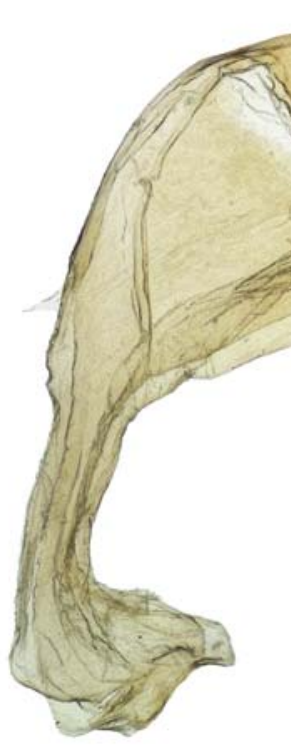

61
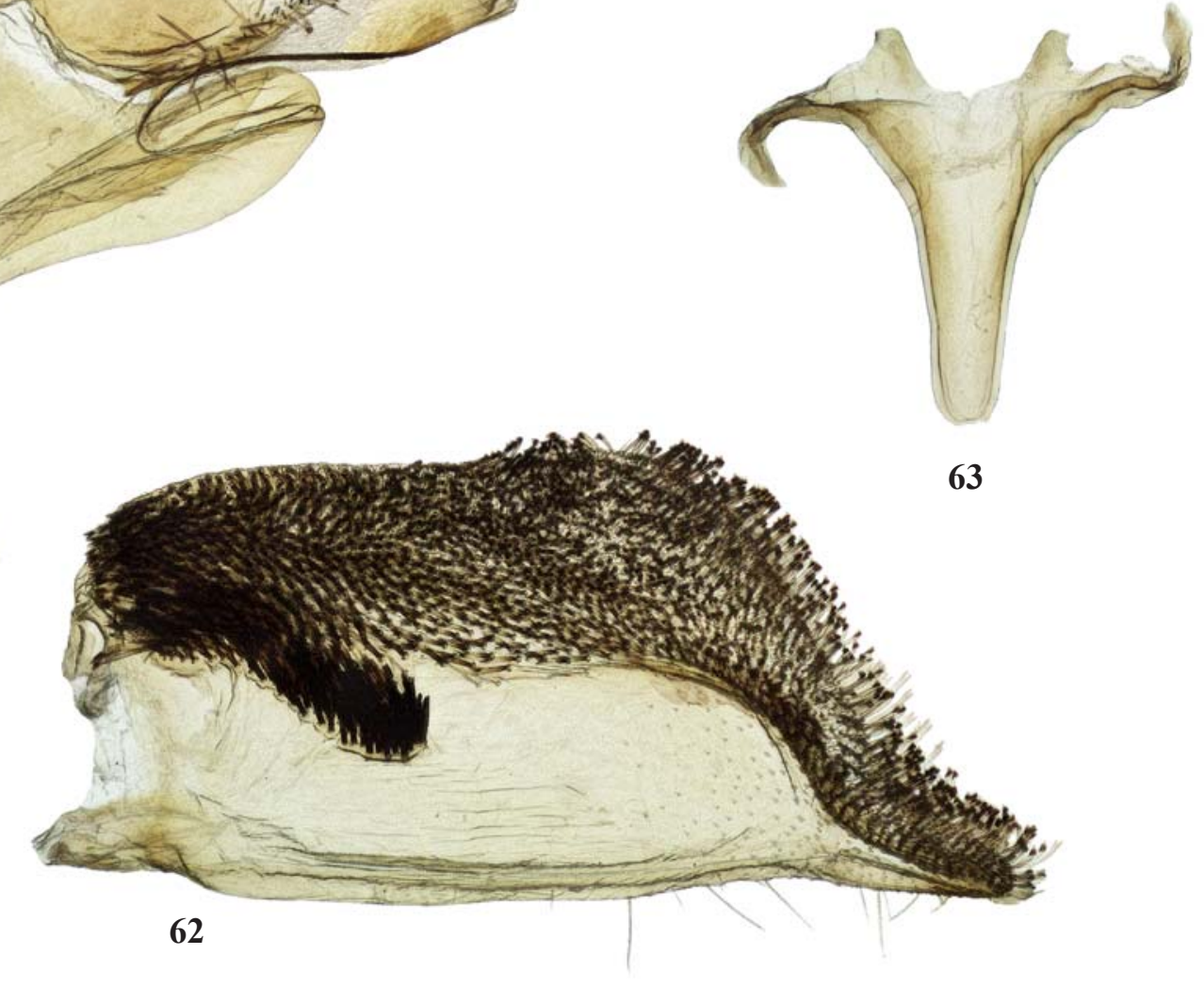

63

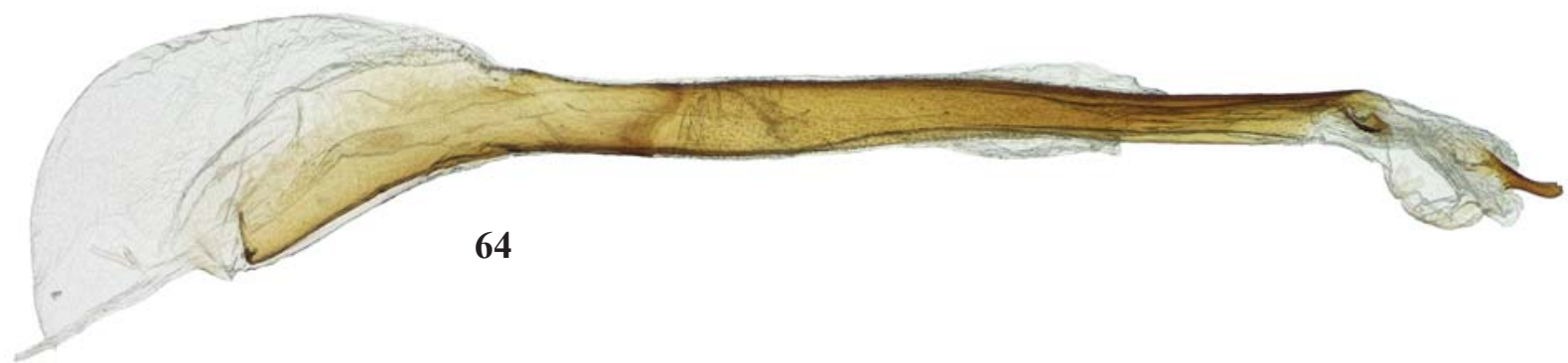

Figs 61-64. Male genitalia of Chamaesphecia efetovi sp.n., paratype, genital preparation № OG-041-2018: 61 — tegumen-uncus complex; 62 - valva; 63 - saccus; 64 - aedeagus. Scale bar: $0.5 \mathrm{~mm}$.

Рис. 61-64. Гениталии самца Chamaesphecia efetovi sp.n., паратип, препарат гениталий № OG-041-2018: 61 — тегумен-ункус комплекс; 62 - вальва; 63 - саккус; 64 - эдеагус. Масштаб: 0,5 мм. 
the number of yellow and yellow-orange scales on the head, thorax, legs and abdomen. The colour of the flying and not very fresh specimens is much paler and with less number of bright scales on the thorax and abdomen. Besides this, the external transparent area of the forewing is slightly variable as well (cp. Figs 17 and 21, and 25 and 29). Individual size is variable as follows. Males: alar expanse 16.5-20.5 mm, body length 9.6$11.5 \mathrm{~mm}$, forewing $7.4-9.2 \mathrm{~mm}$, antenna $5.1-5.4 \mathrm{~mm}$.. Females: alar expanse $16.8-21.0 \mathrm{~mm}$, body length $10.2-11.6$ $\mathrm{mm}$, forewing 7.5-9.2 mm, antenna $4.5-5.1 \mathrm{~mm}$.

DIFFERENTIAL DIAGNOSIS. This new species belongs to $C h$. annellata species-group. A distinctive feature of the species of this group is that they look very similar to each other, but they differ quite well in the size of the transparent areas of the forewing, and, very importantly, in the host-plant of the larvae. Some species of the group are found sympatrically.

Ch. efetovi sp.n. seems to be the closest to Ch. dumonti (Figs 41-56) (type locality: France, Alpes-Maritimes, Valdeblore), from which it can be distinguished by somewhat smaller size of the transparent areas of the forewing (posterior transparent area short and not reaching level of cross-vein of hindwing; external transparent area rather large with rounded distal margin, divided into four, very rarely into five (Figs 21, 23) cells, level to vein $M_{2}$ about 1.75 times as broad as discal spot in males of Ch. efetovi sp.n., vs. posterior transparent area long and reaching level of cross-vein of hindwing; external transparent area large, roundish, divided into five cells, level to vein $\mathrm{M}_{2}$ about 2.0-2.5 times as broad as discal spot in males of Ch. dumonti; posterior transparent area undeveloped; external transparent area small, round, divided into three cells, level to vein $\mathrm{M}_{2}$ about as broad as discal spot in females of Ch. efetovi sp.n., vs. posterior transparent area short and vestigial; external transparent area large, oval or roundish, divided into $3-5$ cells, level to vein $\mathrm{M}_{2}$ about 1.5-2.0 times as broad as discal spot in females of $C h$. dumonti). The host plants of Ch. dumonti are Stachys recta L., S. atherocalyx K.Koch, S. cretica subsp. bulgarica Rech.f. (as S. thracica auct.), S. plumose Griseb. (Lamiaceae).

From Ch. annellata (type locality: "Asia, Tlos" [= Turkey, Mugla Prov., Tlos]), this new species clearly differs by a larger size (alar expanse 16.5-21.0 in Ch. efetovi sp.n., vs. $12.0-18.0$ in the species compared) and more developed external transparent area of the forewing (external transparent area rather large with rounded distal margin, divided into four, very rarely into five (Figs 21,23) cells, level to vein $M_{2}$ about 1.75 times as broad as discal spot in males of $C h$. efetovi sp.n., vs. external transparent area large, elongate, divided into three, very rarely into four cells, level to vein $\mathrm{M}_{2}$ about 1.5 times as broad as discal spot in males of $C h$. annellata; external transparent area large, elongate, divided into three cells, level to vein $\mathrm{M}_{2}$ about 1.2 times as broad as discal spot in males of the species compared). The larvae of Ch. annellata live in roots of Ballota nigra L. (Lamiaceae).

From other species of the Ch. annellata species-group, Ch. efetovi sp.n. is distinguishable by the larger size and more developed transparent areas of the forewing.

BIONOMICS. The larval host-plant is Marrubium peregrinum L. (= M. praecox Janka) (Lamiaceae). It is very likely that $M$. vulgare $\mathrm{L}$. can also be a host-plant of this species in Bulgaria and Romania [Špatenka et al., 1999: 362]. The larva lives in the root where it bores a tunnel about 5-8 $\mathrm{cm}$ long. Its life cycle is annual. Pupation takes place in the upper part of the tunnel in the upper part of the root or lower part of the stem. Moths fly out from the end of June to the second half of July. They can be found sitting on flowers or flying slowly in the thickets of host-plants. Males were collected using synthetic sex attractants for Synanthedon vespiformis (Linnaeus, 1761) produced by PHEROBANK ${ }^{\circledR}$, Wijk bij Duurstede, the Netherlands. They are attracted exclusively from 16:30 to 19:00 local time.

HABITAT. Very diverse open biotopes, but with the obligatory presence of the host plant: herbaceous steppes, abandoned lands, roadsides, clearings in deciduous forests, etc.

DISTRIBUTION. At present, this new species is known from a lot of localities in Crimea, North Caucasus and Volgograd Region (see material). In addition, references to the whereabouts of Ch. oxybeliformis in Bulgaria [Laštůvka, 1983] and Romania [Popesku-Gorj et al., 1958] should refer to this new species.

ETYMOLOGY. This new species is named in honour of my friend Prof. Dr. Konstantin A. Efetov (Crimean Federal University, Simferopol', Russia), a researcher of the Lepidoptera of the Crimean Peninsula and a specialist in the family Zygaenidae of the world fauna.

\section{Chamaesphecia (Scopulosphecia) kalashiani O. Gorbunov, sp.n. \\ Figs 33-40, 65-68, 75.}

= Chamaesphecia dumonti auct. nec Chamaesphecia dumonti Le Cerf, 1922.

LITERATURE. Laštůvka, Laštůvka, 1995: 120 (Chamaesphecia dumonti); de Freina, 1997: 225, figs 47, 48 (Chamaesphecia dumonti); Špatenka et al., 1999: 368 (Chamaesphecia dumonti, part.).

MATERIAL. Holotype $\sigma^{7}$ (Figs 33-34) with labels: "Armenia, Vayots Dzor, / $9.4 \mathrm{~km} \mathrm{SE}\left(158.3^{\circ}\right)$ of Vaik, / 39 $36.82^{\prime} \mathrm{N}, 45^{\circ} 30.33^{\prime} \mathrm{E}$, / 1670 m, 14.VI.1997, ex 1. / O. Gorbunov leg." (white); "Host plant: / Stachys iberica / (Lamiaceae) / Moth emerged 14.VII.1997" (white); "SESIIDAE / Pictures №№ / 0339-0340-2017 / Photo by O. Gorbunov" (white); "HOLOTYPUS OT/ Chamaesphecia kalashiani / O. Gorbunov, 2019 / O. Gorbunov des., 2017" (red) (COGM).

Paratypes (5 $\sigma^{7} \sigma^{7}, 5$ 우) (Figs 35-40): $1 \sigma^{7}$, Armenia, Khosrov $\mathrm{NR}, 19.8 \mathrm{~km} \mathrm{NE}\left(54.5^{\circ}\right)$ of Vedi, $40^{\circ} 00.84^{\prime} \mathrm{N}, 44^{\circ} 54.78^{\prime} \mathrm{E}, 1630 \mathrm{~m}$, 15.VI.1986, O. Gorbunov leg. (COGM); $10^{\gamma}$, Azerbaijan, Nakhchivan, A a i Buzqov, 39 $30.715^{\prime} \mathrm{N}, 45^{\circ} 23.736^{\prime} \mathrm{E}, 1430 \mathrm{~m}$, 02.VII.1986, A. Danchenko leg. (genitalia preparation № OG-0472018) (COGM); 1 + (Figs 39-40), Azerbaijan, Nakhchivan, Biçenək, $39^{\circ} 30.055^{\prime} \mathrm{N}, 4^{\circ} 46.358^{\prime} \mathrm{E}, 1730 \mathrm{~m}, 22$.VII.1986, O. Gorbunov leg. (Sesiidae pictures №№ 0337-0338-2017) (COGM); 1 +, Armenia, Khosrov NR, $19.8 \mathrm{~km} \mathrm{NE}\left(54.5^{\circ}\right)$ of Vedi, $40^{\circ} 00.84^{\prime} \mathrm{N}, 44^{\circ} 54.78^{\prime} \mathrm{E}$, 1630 m, 03.VII.1988, O. Gorbunov leg. (COGM); 1 "7 , Azerbaijan,

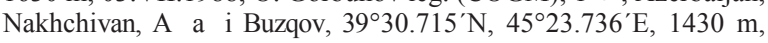
15.VI.1988, ex larva from a root of Stachys iberica (Lamiaceae), moth emerged 02.VII.1988, O. Gorbunov leg. (COGM); $2 \sigma^{7} \sigma^{7}$ (Figs 35-36), 2 우, same locality, 25.VI.1988, ex larvae from roots of Stachys iberica (Lamiaceae), moths emerged 12-14.VII.1988, O. Gorbunov leg. (Sesiidae pictures №№ 0335-0336-2017) (1 ㅇ with genitalia preparation № OG-048-2018) (COGM); 1 + (Figs 37-38), same locality and date as holotype, ex larva from a root of Stachys iberica (Lamiaceae), moth emerged 20.VII.1988, O. Gorbunov leg. (Sesiidae pictures №№ 0341-0342-2017) (COGM).

DESCRIPTION. Male (holotype) (Figs 33, 34) (Sesiidae pictures №№ 0339-0340-2017). Alar expanse $18.0 \mathrm{~mm}$, body length $10.0 \mathrm{~mm}$, forewing $8.0 \mathrm{~mm}$, antenna $5.0 \mathrm{~mm}$.

Head with antenna dark brown to black with dark greenblue sheen dorsally and yellow ventrally, scapus yellow with a few black scales dorsally; frons gray-brown with violet sheen and a broad white stripe laterally; basal joint of labial palpus white, mid joint white with a narrow black stripe exterior-ventrally, apical joint yellow with a narrow gray stripe ventrally; vertex mixed with black with dark violet sheen and a yellow-orange scales; pericephalic hairs yelloworange dorsally and white laterally.

Thorax with patagia dorsally dark brown to black with 
bronze-purple sheen and a few yellow scales anteriorly, ventrally yellow-orange; tegula dark brown to black with blue-violet sheen, with a narrow yellow inner margin and a small pale yellow spot at base of forewing anteriorly; mesothorax dark brown to black with blue-violet sheen, with a narrow yellow stripe anterior-medially; metathorax dark brown to black with blue-violet sheen with a few yellow and pale yellow scales medially and a tuft of yellow hair-like scales laterally; thorax laterally dark-gray brown with violet sheen and a large pale yellow spot anteriorly and a few white scales posteriorly; posteriorly metepimeron dark gray-brown, metameron white, both of them covered with white hair-like scales. Legs with neck plate white with golden hue; fore coxa white with golden hue; fore femur internally white with golden hue, externally gray-brown with bronze sheen, densely covered with yellow scales; fore tibia ventrally yellow, dorsally gray-brown with bronze-violet sheen, a few yellow scales distally and pale yellow elongated scales at posterior margin; fore tarsus ventrally pale yellow, dorsally basal tarsomere dark gray-brown with bronze-violet sheen and a large yellow spot posteriorly, remaining tarsomeres dark gray-brown with bronze-violet sheen; mid coxa anteriorly mixed with dark gray-brown with bronze-violet sheen and yellow scales with golden hue, posteriorly white to pale yellow with golden hue; mid femur internally pale yellow, externally dark gray-brown with bronze-violet sheen, a dense admixture of yellow scales anteriorly and a small pale yellow spot posterior-distally; mid tibia internally pale yellow, externally mixes with dark gray-brown with violet sheen and yellow with golden hue scales, a large white spot sub basally and a few white scales dorso-distally; spurs white with golden hue; mid tarsus internally pale yellow with golden hue, externally basal tarsomere pale yellow with golden hue and a longitudinal dark gray-brown spot with bronze-green sheen medially, second tarsomere dark gray-brown with bronzegreen sheen and a few pale yellow scales distally, remaining tarsomeres dark gray-brown with bronze-green sheen; hind coxa yellow to pale yellow with golden hue; hind femur internally pale yellow, externally dark gray-brown with bronzeviolet sheen, a dense admixture of yellow scales anteriorly and a small pale yellow spot posterior-distally; hind tibia pale yellow with golden hue, with white scales both dorso-medially and dorso-distally and dark gray-brown scales with bronzeviolet sheen both ventrally from base to base of mid spurs and distally; spurs white with golden hue; hind tarsus internally pale yellow, externally basal tarsomere yellow with golden

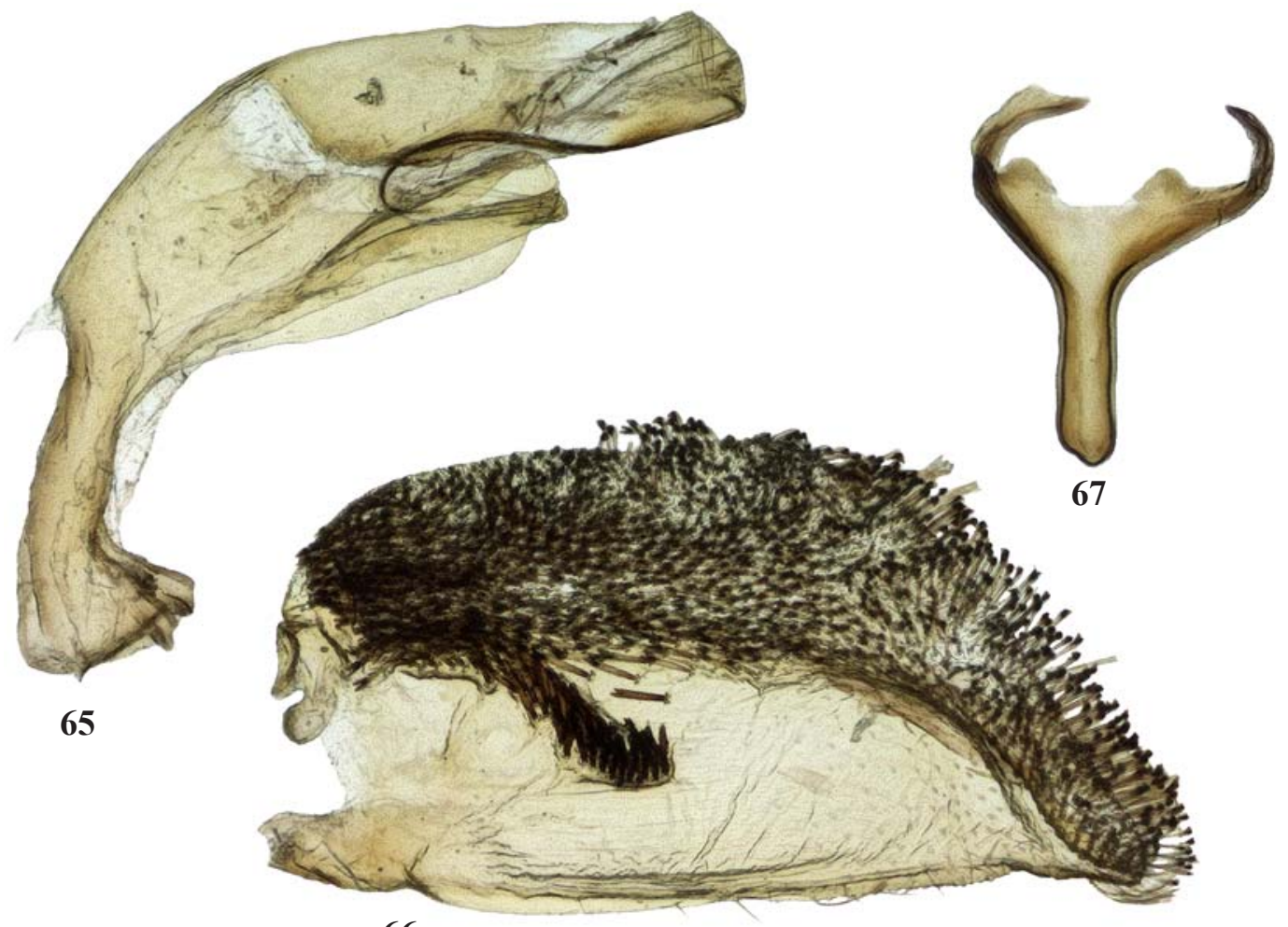

66

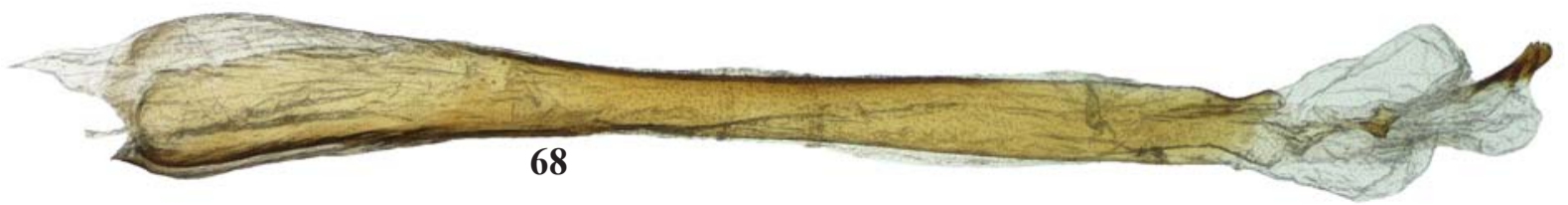

Figs 65-68. Male genitalia of Chamaesphecia kalashiani sp.n., paratype, genital preparation № OG-051-2018: 65 — tegumen-uncus complex; 66 - valva; 67 - saccus; 68 - aedeagus. Scale bar: $0.5 \mathrm{~mm}$.

Рис. 65-68. Гениталии самца Chamaesphecia kalashiani sp.n., паратип, препарат гениталий № OG-051-2018: 65 — тегумен-ункус комплекс; 66 - вальва; 67 - саккус; 68 - эдеагус. Масштаб: 0,5 мм. 
hue, remaining tarsomeres entirely dark gray-brown scales with bronze-violet sheen. Forewing dorsally black with blueviolet sheen at base; costal margin dark brown with dark blue-violet sheen; anal margin, CuA-stem and discal spot dark brown with bronze sheen; veins within external transparent area dark brown with bronze sheen and a few yellow scales; apical area dark brown with bronze sheen and an admixture of yellow scales between veins $\mathrm{R}_{4}-\mathrm{M}_{2}$; discal spot somewhat darker trapeziform; transparent area well-developed, but posterior transparent area short and not reaching level of cross-vein of hindwing; external transparent area large with rounded distal margin, divided into five cells between veins $\mathrm{R}_{3}$ and $\mathrm{CuA}_{1}$, level to vein $\mathrm{M}_{2}$ about thrice as broad as discal spot and apical area; ventrally costal and anal margins and $\mathrm{CuA}$-stem yellow to pale yellow from base to discal spot; discal spot and surface between veins $\mathrm{R}_{1}-\mathrm{R}_{3}$ dark brown to black with dark violet sheen; surface between veins $\mathrm{CuA}_{1}-\mathrm{CuA}_{2}$ dark brown to black with bronze sheen; veins within external transparent area yellow to pale yellow with a few dark brown scales distally; apical area dark brown to black with bronze sheen and a dense admixture of yellow to pale yellow between veins $\mathrm{R}_{3}-\mathrm{M}_{3}$; cilia dark brown basally and pale yellow distally. Hindwing transparent; dorsally veins, discal spot and outer margin dark brown with bronze sheen; discal spot with parallel margins and a very short projection on vein $\mathrm{M}_{2}$, relatively narrow, about 0.5 times as broad as outer margin, reaching base of veins $\mathrm{M}_{3}-\mathrm{CuA}$; outer margin narrow about 0.5 as broad as cilia; ventrally veins yellow; discal spot and outer margin dark brown with bronze sheen with a few dark brown scales; cilia dark brown basally and pale yellow distally.

Abdomen dorsally dark brown to black with bronzeviolet sheen; tergites 2, 6 and 7 each with a narrow pale yellow stripe with golden hue distally; tergite 4 with broader pale yellow stripe with golden hue distally; tergites 3 and 5 each with a few pale yellow scales with golden sheen distally;
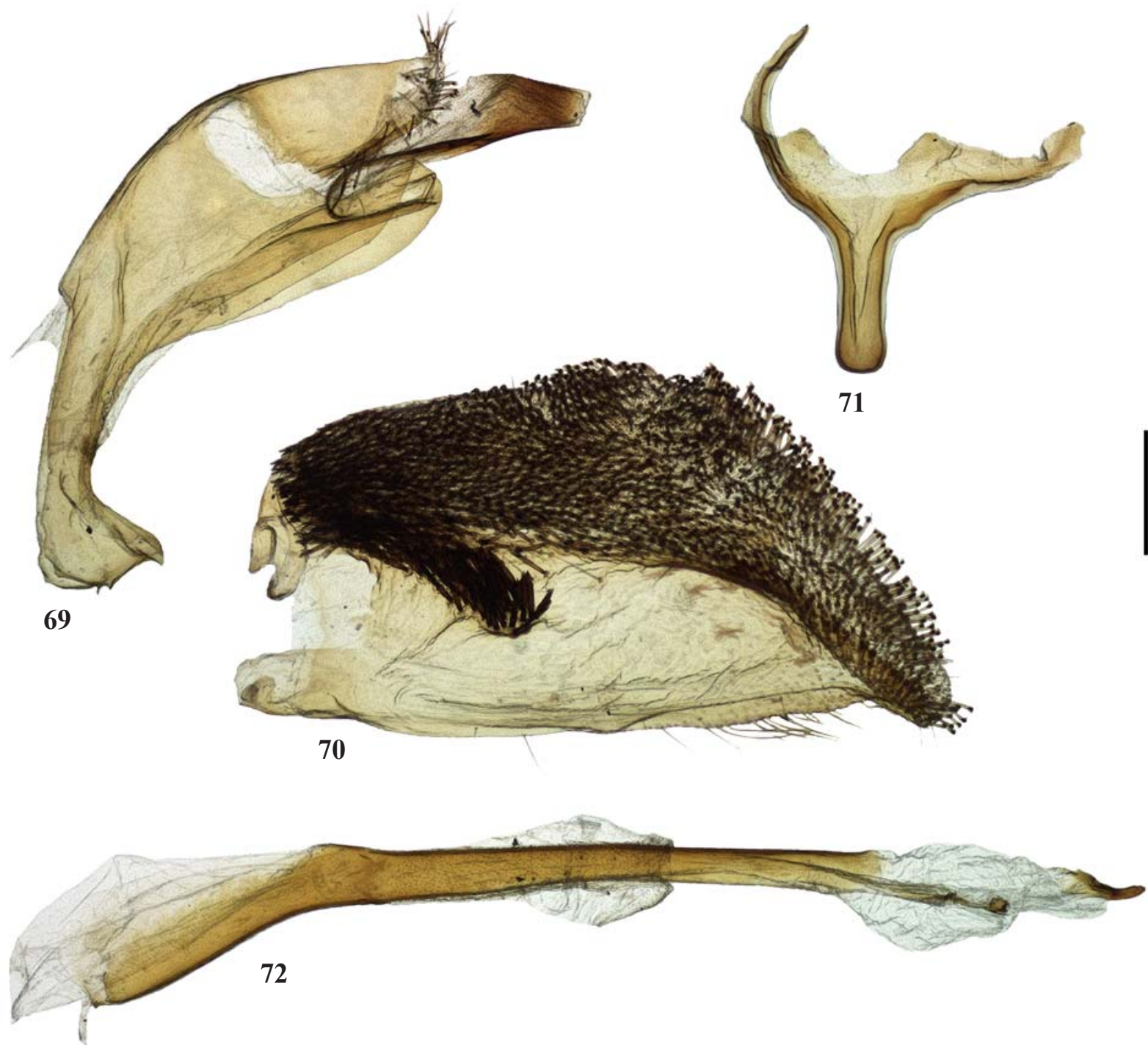

Figs 69-72. Male genitalia of Chamaesphecia dumonti Le Cerf, 1922. Ukraine, Crimea, Kerch peninsula, Bagerovo, $45^{\circ} 23.014^{\prime} \mathrm{N}$, 036 ${ }^{\circ}$ 18.221' E, 95 m, 08.V.2013, ex l., O. Gorbunov leg. (COGM). Genital preparation № OG-042-2018: 69 — tegumen-uncus complex; 70 - valva; 71 - saccus; 72 - aedeagus. Scale bar: $0.5 \mathrm{~mm}$.

Рис. 69-72. Гениталии самца Chamaesphecia dumonti Le Cerf, 1922. Крым, Керченский полуостров, Багерово, 45²3.014’ c.ш., 036 $18.221^{\prime}$ в.д., 95 м, 08.V.2013, ex l., О. Горбунов (COGM). Препарат гениталий № OG-042-2018: 69 — тегумен-ункус комплекс; 70 - вальва; 71 - саккус; 72 - эдеагус. Масштаб: 0,5 мм. 
tergites 2 and 4 each with a narrow yellow stripe subdistally; tergite 3 with a broad yellow stripe medially; tergites 5-7 each densely covered with yellow scales; laterally sternite $1+2$ pale yellow; ventrally dark brown with dark blue-violet sheen; sternite $1+2$ pale yellow to white in distal half; sternite 4 with a narrow pale yellow to white stripe distally; sternites 3-7 each with a dense admixture of yellow scales; anal tuft dark brown to black with dark bronze-violet sheen laterally and pale yellow to yellow medially and ventrally.

Male genitalia (Figs 65-68). Paratype. Genital preparation № OG-047-2018.

Female (paratype) (Figs 37-38) (Sesiidae pictures №№ 0341-0342-2017). Alar expanse $16.0 \mathrm{~mm}$, body length 8.2 $\mathrm{mm}$, forewing $7.1 \mathrm{~mm}$, antenna $4.4 \mathrm{~mm}$.

Head with mid labial joint with a few black scales exterior-distally. Transparent areas of forewing less developed, posterior transparent area undeveloped, external transparent area round, divided into five cells (cells between veins $R_{3}-$ $\mathrm{R}_{4+5}$ and $\mathrm{M}_{3}-\mathrm{CuA}$, extremely small), level to vein $\mathrm{M}_{2}$ about twice as broad as discal spot and about 1.2 times broader than apical area. Discal spot of hindwing somewhat broader, slightly more broad than outer margin.

Abdomen with tergites 2, 4 and 6 each with a narrow pale yellow stripe with golden hue distally; tergites 4-6 each with a narrow yellow stripe subdistally; anal tuft medially mixed with dark brown to black with dark bronze-violet sheen and yellow-orange scales.

Otherwise colour pattern as in male (holotype).

Female genitalia (Fig. 75). Paratype. Genital preparation № OG-048-2018.

INDIVIDUAL VARIABILITY. Both males (Figs 3336) and females (Figs 37-40) vary in the number of yellow, pale yellow or yellow-orange scales on the head, thorax, legs, and abdomen. The colour of the flying and not very fresh specimens is much paler and with less number of yellow scales on the thorax and abdomen. Individual size is variable as follows. Males: alar expanse $17.0-18.0 \mathrm{~mm}$, body length 8.7-10.0 mm, forewing 7.4-8.0 mm, antenna $4.7-5.0 \mathrm{~mm}$.
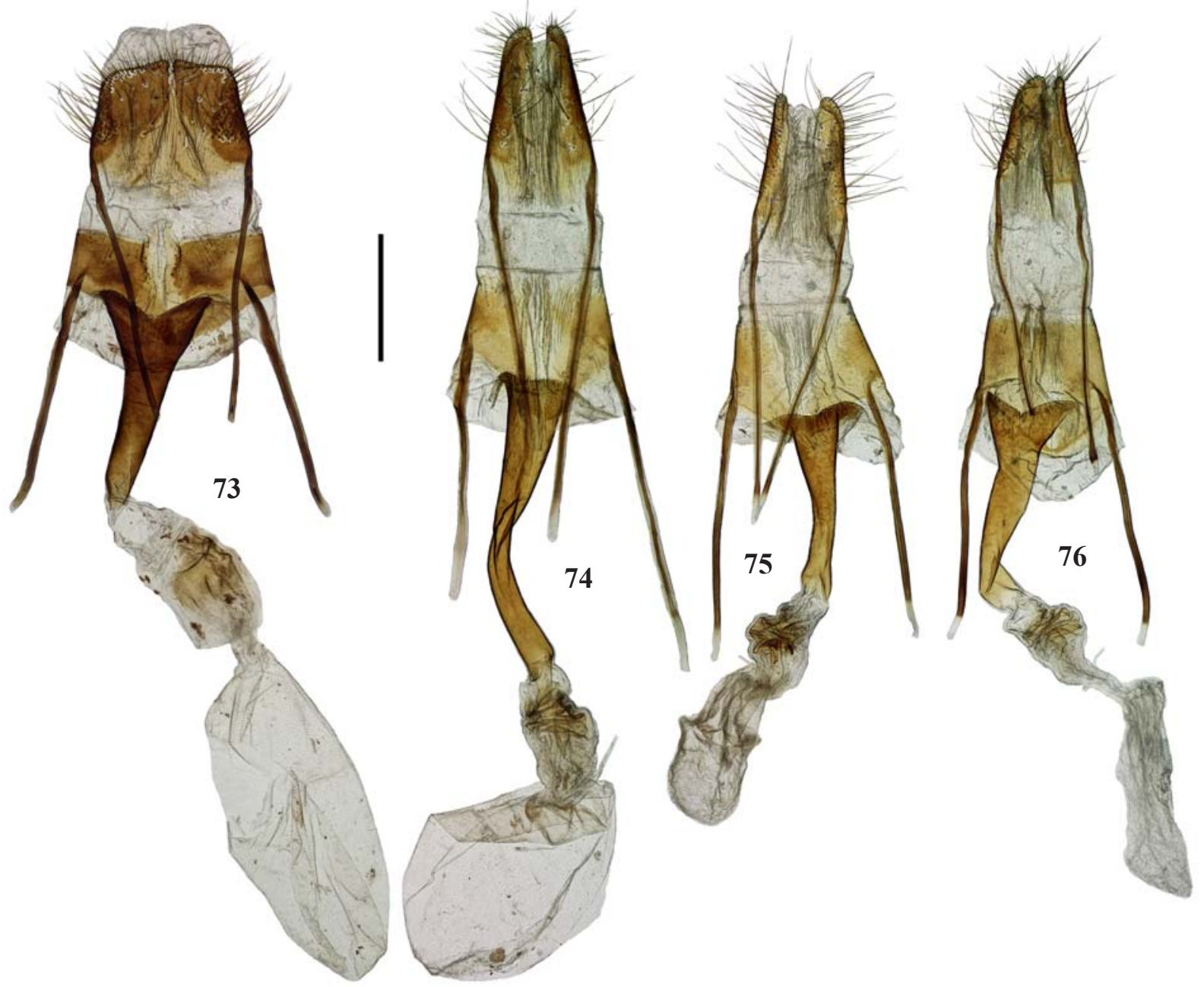

Figs 73-76. Female genitalia of Chamaesphecia spp: 73 - Chamaesphecia oxybeliformis (Herrich-Schäffer, 1846), genital preparation № OG-024-2018; 74 - Chamaesphecia efetovi sp.n., paratype, genital preparation № OG-049-2018; 75 - Chamaesphecia kalashiani sp.n., paratype, genital preparation № OG-048-2018; 76 — Chamaesphecia dumonti Le Cerf, 1922, genital preparation № OG-043-2018. Scale bar: $0.5 \mathrm{~mm}$.

Рис. 73-76. Гениталии самок Chamaesphecia spp: 73 - Chamaesphecia oxybeliformis (Herrich-Schäffer, 1846), препарат гениталий № OG-024-2018; 74 - Chamaesphecia efetovi sp.n., паратип, препарат гениталий № OG-049-2018; 75 — Chamaesphecia kalashiani sp.n., паратип, препарат гениталий № OG-048-2018; 76 - Chamaesphecia dumonti Le Cerf, 1922, препарат гениталий № OG-043-2018. Масштаб: 0,5 мм. 


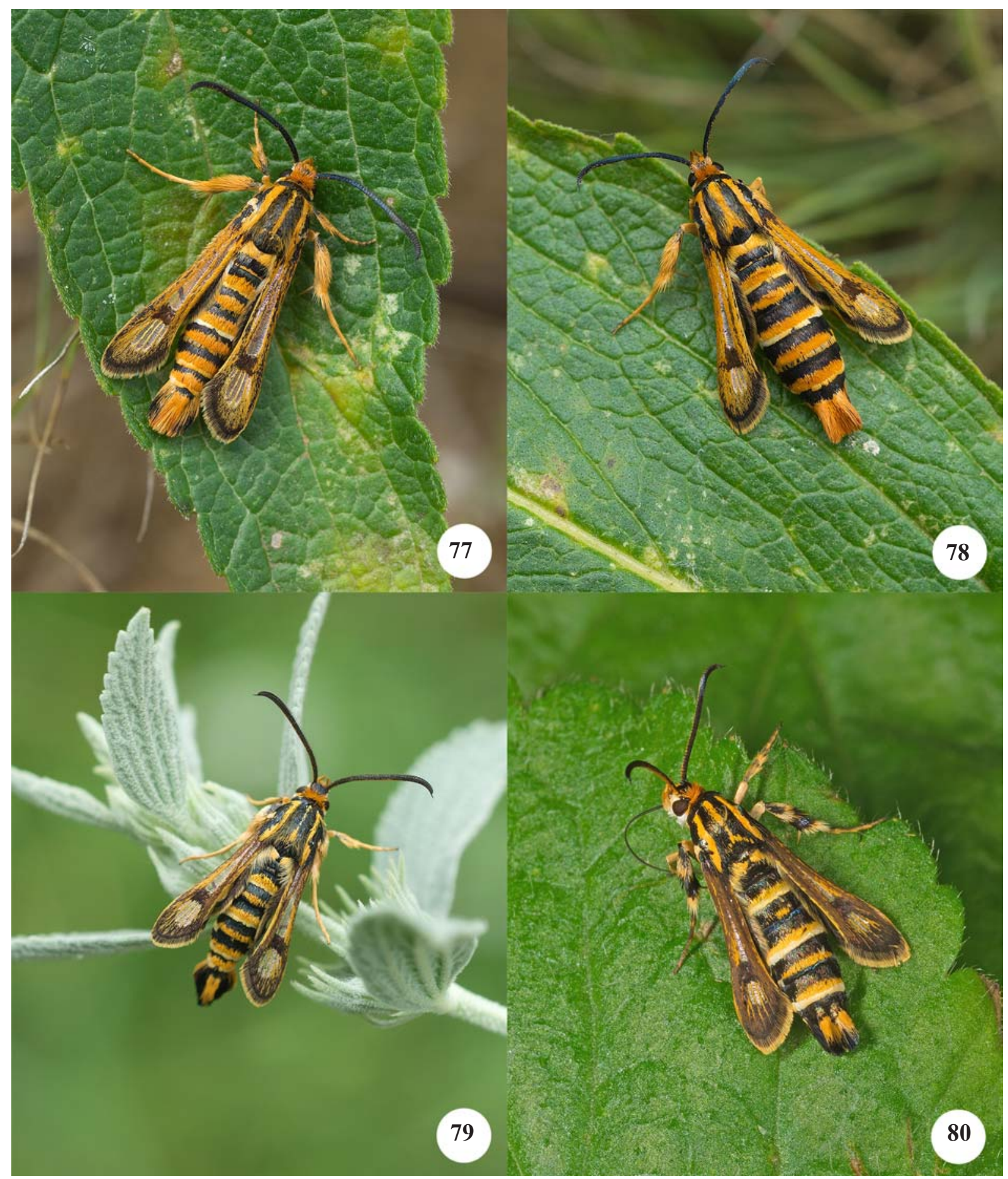

Figs 77-80. Life history of Chamaesphecia spp.: 77 - Chamaesphecia oxybeliformis (Herrich-Schäffer, 1846), male. Russia, Crimea,

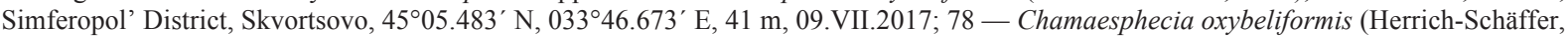

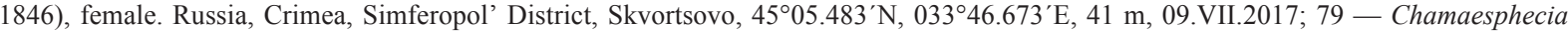

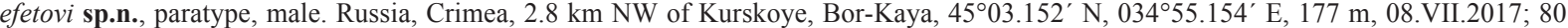
- Chamaesphecia efetovi sp.n., paratype, female. Russia, Crimea, Tarkhankut, Kipchak ravine, $45^{\circ} 28.48^{\prime} \mathrm{N}, 032^{\circ} 35.87^{\prime} \mathrm{E}, 10^{\prime} \mathrm{m}$, 14.V.2016, ex larvae from roots of Marrubium peregrinum (Lamiaceae), moths emerged 29.VI.2016.

Рис. 77-80. Биология Chamaesphecia spp.: 77 - Chamaesphecia oxybeliformis (Herrich-Schäffer, 1846), самец. Россия, Крым, Симферопольский район, Скворцово, 4505.483' с.ш., 03346.673’ в.д., 41 м, 09.VII.2017; 78 - Chamaesphecia oxybeliformis

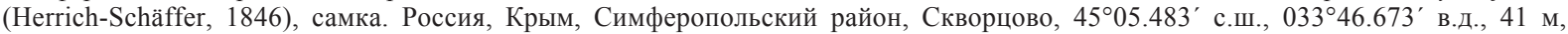
09.VII.2017; 79 - Chamaesphecia efetovi sp.n., паратип, самец. Россия, Крым, 2,8 км СЗ Курского, Бор-Кая, 4503.152' с.ш., 0345ㄷ.154' в.д., 177 м, 08.VII.2017; 80 - Chamaesphecia efetovi sp.n., паратип, самка. Россия, Крым, Тарханкут, Балка Кипчак,

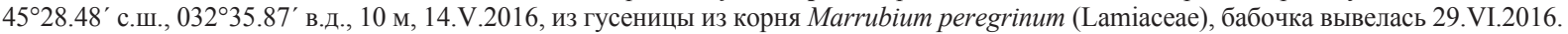


Females: alar expanse $16.0-17.0 \mathrm{~mm}$, body length $8.2-8.7$ $\mathrm{mm}$, forewing 7.1-7.5 mm, antenna 4.4-4.6 mm.

DIFFERENTIAL DIAGNOSIS. This new species belongs to Ch. annellata species-group and seems to be the closest to Ch. dumonti (Figs 41-56), from which it can be distinguished by a smaller size (alar expanse 16.0-18.0 in Ch. kalashiani sp.n., vs. 17.0-21.0 in the species compared). Males of Ch. kalashiani sp.n., differ from males of $C h$. dumonti by relatively larger external transparent area (divided into five cells between veins $R_{3}$ and $C u A_{1}$, level to vein $M_{2}$ about thrice as broad as discal spot in Ch. kalashiani sp.n., vs. divided into five or even six cells between veins $\mathrm{R}_{3}$ and $\mathrm{CuA}$, level to vein $\mathrm{M}_{2}$ about 2.5 times as broad as discal spot in $C h$. kalashiani) and smaller posterior transparent area of the forewing (short and not reaching level of cross-vein of hindwing in Ch. kalashiani sp.n., vs. long and exceeding level of cross-vein of hindwing in Ch. dumonti; cp. Figs 33-36 with Figs 41-48). In addition, the males of this new species look somewhat more yellow due to the greater number of yellow scales on the apical area of the forewing and abdomen. Females of this new species can be separated from females of Ch. dumonti by relatively larger discal spot of the hindwing (cp. Figs 37-39 and 49-56). Besides this, these two species clearly differ from each other by the structure of both male and female genitalia (compare Figs $65-68$ and Figs 69-72, Fig. 75 and Fig. 76)

From Ch. diabarensis Gorbunov, 1987 (type locality: Azerbaijan, Talysh Mts., Zuvand), this new species is distinguishable by the colouration of the hind tibia (pale yellow with golden hue, with white scales both dorso-medially and dorso-distally and dark gray-brown scales with bronze-violet sheen both ventrally from base to base of mid spurs and distally in Ch. kalashiani sp.n., vs. white with an indistinct in male and broad in female black ring with dark violet sheen both basally and at base of apical spurs in the species compared) and forewing (costal margin dark brown with dark blue-violet sheen; anal margin, $\mathrm{CuA}$-stem and discal spot dark brown with bronze sheen; veins within external transparent area dark brown with bronze sheen and a few yellow scales; apical area dark brown with bronze sheen and an admixture of yellow scales between veins $\mathrm{R}_{4}-\mathrm{M}_{2}$ in $C h$. kalashiani sp.n., vs. costal and anal margins and CuA-stem dark brown with bronze-violet sheen sheen, densely covered with brownish and a few yellow scales masking background colouration, discal spot dark brown to black with dark violet sheen; veins within external transparent area dark brown with bronze sheen and a few yellow scales; apical area dark brown with bronze sheen and an admixture of yellow scales between veins $\mathrm{R}_{4}-\mathrm{M}_{3}$ in Ch. diabarensis), by relatively larger external transparent area of the forewing in male (divided into five cells between veins $\mathrm{R}_{3}$ and $\mathrm{CuA}$, level to vein $\mathrm{M}_{2}$ about thrice as broad as discal spot in Ch. kalashiani sp.n., vs. divided into four cells between veins $\mathrm{R}_{4+5}$ and $\mathrm{CuA}$, level to vein $\mathrm{M}_{2}$ about twice as broad as discal spot of $C h$. diabarensis). The host plants of Ch. diabarensis is Marrubium persicum C.A.Mey (Lamiaceae).

From Ch. albida Śpatenka, 1999 (type locality: Turkey, Taurus Mts., Sertavul pass), Ch. kalashiani sp.n., clearly differs by the presence of yellow scales on legs and wings (white in the species compared) therefore it looks much yellower. The host plants of Ch. albida is Sideritis syriaca $\mathrm{L}$. (Lamiaceae).

BIONOMICS. The larval host-plant is Stachys iberica M. Bieb. (Lamiaceae). The larva lives in the root where bores a tunnel about 7-9 $\mathrm{cm}$ long. It lives during a year and pupates in the upper part of the root. Moths are on the wing from the
mid-June to mid-July.

HABITAT. Xerophytic grassy slopes, glades in broadleaved forests at altitudes of about 1400-1800 m above sea level.

DISTRIBUTION. The new species is known from a few localities in Armenia and Azerbaijan within the Daralagez and Zangezur mountain ranges at altitudes of 1400-1800 m.

ETYMOLOGY. This new species is named after my friend Dr. Mark Yu. Kalashian (Scientific Center of Zoology and Hydroecology, National Academy of Sciences of Armenia, Yerevan, Armenia), a researcher of Buprestidae (Coleoptera) of the world fauna.

Acknowledgements. I express my cordial gratitude to Prof. Dr. Konstantin A. Efetov (Simferopol, Russia) for his constant help in my research of the Crimean Sesiidae. Many thanks to Prof. Dr. Andrey V. Yena (Simferopol, Russia) for his help in determining the host-plants of the Crimean Sesiidae. I also thank Dr. Mark Yu. Kalashian (Erevan, Armenia) for help and assistance during my collecting trips to Armenia, and Aleksandr L. Lvovsky, Aleksei Yu. Matov and Sergei Yu. Sinev (St. Petersburg, Russia) for the opportunity to work with the collection of the Zoological Institute of the Russian Academy of Sciences. I am indebted to Mr. Vlad Proklov (London, England) for carefully checking the English of an advanced draft.

The study was conducted using the equipment of the Joint Usage Center "Instrumental methods in ecology" at the A.N. Severtsov Institute of Ecology and Evolution, Russian Academy of Sciences (Moscow, Russia).

\section{References}

Anikin V.A., Sachkov S.A., Zolotuhin V.V. 2017. Sesiidae // "Fauna Lepidopterologica Volgo-Uralensis": from P. Pallas to present day // Proc. Mus. Witt. Vol.7. P.144-147.

Bartel M. 1912. 24. Familie: Aegeriidae (Sesiidae) // Seitz A. (Hrsg.). Die Gros-Schmetterlinge der Erde. Bd.2. Die Palaearktischen Spinner \& Schwärmer. Stuttgart: A Kernen Verlag. S.375-416. Pl. 51-52.

Dalla Torre K.W., Strand E. 1925. Aegeriidae // Strand E. (Hrsg.). Lepidopterorum Catalogus. Bd.31. Berlin: W. Junk. $202 \mathrm{~S}$.

Freina J.J., de. 1997. Die Bombyces und Sphinges der Westpalaearktis (Insecta, Lepidoptera). Vol.4. Sesioidea: Sesiidae. Munchen: EFW Edition Forschung und Wissenschaft Verlag GmbH. 432 S., $27 \mathrm{pl}$.

Gorbunov O.G. 2008. [Sesiidae] // Sinev S.Yu. (ed.). Catalogue of the Lepidoptera of Russia. Moscow, Saint Petersburg: KMK Scientific Press. P.110-112 [in Russian].

Gorbunov O.G. 2013. [To the fauna of clearwing moths (Lepidoptera, Sesiidae) of Malyi Utrish, Abrau Peninsula] // Krokhmal A.G. (ed.). Biodiversity of the "Utrish" State Nature Reserve. Vol.1. Anapa. P.259-276 [in Russian].

Heppner J.B., Duckworth W.D. 1981. Classification of the Superfamily Sesioidea (Lepidoptera, Ditrysia) // Smithsonian Contr. Zool. Vol.314. P.1-144.

Herrich-Schäffer G.A.W. 1846. Systematische Bearbeitung der Schmetterlinge von Europa, zugleich als Text, Revision und Supplement zu Jakob Hübner's Sammlung europäischer Schmetterlinge. Zweiter Band. Die Schwärmer, Spinner und Eulen. Regensburg. S.1-104. Pl. 1-8.

ICZN (The International commission on zoological nomenclature), 1999. International Code of zoological nomenclature. 4th Edition. London: The International trust for zoological nomenclature, xxix $+309 \mathrm{pp}$.

Laštůvka Z. 1983. Two new species of the genus Chamaesphecia Spul. (Sesiidae) from Central and South-east Europe // Acta Univ. Agricult., Fac. Agron. Vol.31. Nos1-2. P.199-214. 
Laštůvka Z. 1990a. Zur Taxonomie der Gattungen Chamaesphecia Spuler, Synansphecia Căpuşe und Dipchasphecia Căpuşe (Lepidoptera, Sesiidae) // Acta Univ. Agricult., Fac. agron. Vol.36. No.1. S.93-103.

Laštůvka Z. 1990b. Der Katalog der Europäischen Glasflügler (Lepidoptera, Sesiidae) // Scripta J. Fac. Sci. Masaryk Univ. Brno. Vol.20. Nos 9-10. S.461-476.

Laštůvka Z. 1992. Zur Systematik der paläarktischen Gattungen der Tribus Synanthedonini. 2. Phylogenese (Lepidoptera, Sesiidae) // Acta Univ. Agricult., Fac. agron. Vol.38. Nos3-4. S.235-243.

Laštůvka Z., Laštůvka A. 1995. An Illustrated Key to European Sesiidae (Lepidoptera). Brno: Mendel University of Agriculture and Forestry. 173 pp., 8 pls.

Laštůvka Z., Laštůvka A. 2001. The Sesiidae of Europe. Stenstrup: Apollo Books. 245 pp., 9 pls.

Popescu-Gorj A., Niculescu E., Alexinschi A. 1958. Lepidoptera, Familia Aegeriidae // Fauna Republici Populäre Romîne: Insecta. Vol.11. No.1. 195 pp.

Pühringer F., Kallies A. 2004. Provisional checklist of the Sesiidae of the world (Lepidoptera: Ditrysia) // Mitt. Ent. Arb.gem. Salzkammergut. Vol.4. P.1-85.
Špatenka K., Gorbunov O., Laštůvka Z., Toševski I., Arita Y. 1999. Sesiidae, Clearwing Moths // Naumann C.M. (ed.). Handbook of Palaearctic Macrolepidoptera. Vol.1. Wallingford: Gem Publishing Company. 569 pp., 57 pls.

Špatenka K., Laštůvka Z., Gorbunov O.G., Toševski I., Arita Y. 1993. Die Systematik und Synonymie der paläarktischen Glasflügler-Arten (Lepidoptera, Sesiidae) // Nachr. Ent. Ver. Apollo (N.F.). Bd.14. H.2. S.81-114.

Spuler A. 1910. XXXV. Fam. Aegeriidae. Glasflugler// Hoffman E. (Hrsg.). Die Schmetterlinge Europas. Bd.2. Stuttgart: E. Schweizerbart. P.305-317. Pls.20, 75, 79.

Staudinger O. 1871. II. Sesiidae HS. // Staudinger O., Wocke M. Catalog der Lepidopteren des Europaeischen Faunengebiets. Dresden. S.38-43.

Staudinger O. 1901. 1. Theil: Famil. Papilionidae - Hepialidae // Staudinger O., Rebel H. Catalog der Lepidopteren des palaearktischen Faunengebietes. Berlin: R. Friedländer \& Sohn. xxxii $+411 \mathrm{~S}$.

Sterzl O. 1967. Prodromus Der Lepidopterenfauna von Niederösterreich // Zool.-Bot. Ges. Österreich. Bd.107. S.75-193. 